\title{
Identifying oxygen minimum zone-type biogeochemical cycling in Earth history using inorganic geochemical proxies
}

\author{
Florian Scholz*
}

GEOMAR Helmholtz Centre for Ocean Research Kiel, Wischhofstraße 1-3, 24148 Kiel, Germany

$5 \quad *$ Corresponding author: e-mail: fscholz@geomar.de, phone: +49 (0)431 6002113

\begin{abstract}
Because of anthropogenic global warming, the world ocean is currently losing oxygen. This trend called ocean deoxygenation is particularly pronounced in low-latitude upwelling-related oxygen minimum zones (OMZs). In these areas, the temperature-related oxygen drawdown is additionally modulated by biogeochemical feedback mechanisms between sedimentary iron (Fe) and phosphorus release, water column nitrogen cycling and primary productivity. Similar feedbacks were likely active during past periods of global warming and ocean deoxygenation. However, their integrated role in amplifying or mitigating climate change-driven ocean anoxia has not been evaluated in a systematic fashion. Moreover, many studies on past (de)oxygenation events emphasize anoxic-sulfidic (i.e., euxinic) basins such as the Black Sea rather than upwelling-related OMZs as modern analogue systems.
\end{abstract}

In this review, I summarize the current state of knowledge on biogeochemical processes in the water column and sediments of OMZs. Nitrate-reducing (i.e., nitrogenous) to weakly sulfidic conditions in the water column and Fe-reducing (i.e., ferruginous) to sulfidic conditions in the surface sediment are identified as key-features of anoxic OMZs in the modern ocean. A toolbox of paleo-redox proxies is proposed that can be used to identify OMZ-type biogeochemical cycling in the geological record. By using a generalized model of sedimentary Fe release and trapping, I demonstrate that the extent of Fe mobilization and transport in modern OMZs is comparable to that inferred for the euxinic Black Sea and ferruginous water columns in Earth history. Based on this result, I suggest that many sedimentary Fe enrichments in the geological record are broadly consistent with OMZ-type redox conditions in the water column and surface sediment, especially if enhanced chemical weathering and reactive Fe supply to the ocean during past periods of global warming are taken into account. Future studies on paleo(de)oxygenation events with a combined focus on Fe, sulfur and nitrogen cycling may reveal that OMZtype redox conditions were an important feature of the ocean through Earth's history. 
Keywords: Paleo-redox, oxygen minimum zone, feedback, nitrogenous, ferruginous, euxinic.

\section{Introduction}

The currently observed trend of ocean deoxygenation poses a severe threat to marine ecosystems (Diaz, 2001; Diaz and Rosenberg, 2008). Moreover, ocean anoxia is regarded as one of the main causes for extinction events in Earth history (Meyer and Kump, 2008). As a consequence, there is a growing and converging interest in the biogeochemistry of oxygen-deficient ocean regions across different scientific communities.

A recent global compilation of dissolved oxygen data suggests that the ocean has lost $2 \%$ of its oxygen content over the last few decades (Schmidtko et al., 2017). An important part of this trend is related to anthropogenic global warming, which increases ocean stratification and reduces ventilation by impeding deep convection of oxygenated surface water. In addition, the solubility of oxygen in seawater decreases with increasing temperature (Benson and Krause, 1980; Mataer and Hirst, 2003; Keeling et al., 2011). Changes in land use have led to enhanced nutrient inputs to the coastal ocean, which has resulted in increased primary production, carbon export and respiratory oxygen consumption in subsurface waters (Rabalais et al., 2010; Howarth et al., 2011). Hotspots of ocean deoxygenation are the tropical oxygen minimum zones (OMZs) where upwelling of nutrient-rich water generates an environment with high primary production and naturally low to zero oxygen concentrations in the subsurface ( 100 - 900 $\mathrm{m}$ water depth). Human-induced global environmental change causes an additional oxygen drawdown and spatial expansion of these tropical OMZs (Stramma et al., 2008). In addition to physical mechanisms and external nutrient inputs, the intensity and spatial extent of OMZs is regulated by internal biogeochemical feedback mechanisms. Upon oxygen depletion, fixed nitrogen loss through denitrification reduces the nitrate concentration in upwelling water masses, thus imposing a negative feedback on primary production, carbon export and oxygen consumption (Canfield et al., 2006). In contrast, enhanced recycling of phosphorus and iron from anoxic sediments are a positive feedback for primary production (Ingall and Jahnke, 1994; Van Capellen and Ingall, 1994; Wallmann, 2003; Scholz et al., 2014a). Whether OMZ intensity and expansion will be amplified or mitigated by these feedback mechanisms in the future depends on complex interactions between the marine biogeochemical cycles of nitrogen, phosphorus, iron and sulfur and is a matter of ongoing debate (e.g., Canfield et al., 2006; Ulloa et al., 2012; Landolfi et al., 2013; Scholz et al., 2014a).

Since many biotic crises in Earth's history were associated with ocean anoxia (Meyer and Kump, 2008), paleoceanographers, geobiologists and other scientists working on paleo-environmental 
60 perturbations have a long-standing interest in ocean deoxygenation. Traditionally, semi-restricted basins with anoxic and sulfidic (commonly referred to as euxinic) conditions in the deep water such as the Black Sea were considered to be the best modern analogue environments for ocean anoxia in the geological past (e.g., Lyons et al., 2009). However, oxygen drawdown and euxinia in these silled basins is related to freshwater input and sluggish circulation, which results in an excessively long deep water residence time compared to open-marine environments. The comparability of anoxic continental margin settings in the geological past with modern euxinic basins is therefore limited, especially if causal connections between biogeochemical feedbacks and anoxia are to be established. As a consequence, there is a growing interest in OMZs as potential analogue environments for biogeochemical cycling within the context of open-marine anoxia in Earth history (e.g., Zhang et al., 2016; Hammarlund et al., 2017; Guilbaud et al., 2018). Recent studies hypothesized that OMZ-type redox structures have existed at least since the Mesoproterozoic (1400 Ma ago) (Zhang et al., 2016).

The goal of this review is to synthesize recent research findings on biogeochemical processes in the water column and sediments of OMZs, and how these become registered in sedimentary archives. Much of this synthesis will be based on understanding biogeochemical cycling and the development of paleoredox proxy signatures in the Peruvian OMZ (Fig. 1) and the euxinic Black Sea (Fig. 2). These two anoxic marine environments are considered to be type localities for open-marine and silled basin-type anoxia. Moreover, they are comparably well-studied using state-of-the-art paleo-redox proxies that are commonly applied in studies on biogeochemical cycling in pre-Cenozoic Earth history (i.e., iron speciation, redox-sensitive trace metals). Other pronounced OMZs (northeast equatorial Pacific, Arabian

80 Sea, Benguela upwelling) will also be considered provided that pertinent data are available. Euxinic basins with less restricted deep water compared to the Black Sea (e.g., Baltic Sea Deeps, Cariaco Basin) are considered to be intermediate systems that share characteristics with both open-marine OMZs and the Black Sea (e.g., Algeo and Lyons, 2006; Scholz et al., 2013). For sake of clarity, I will not explicitly refer to these intermediate environments in this article.

85 Many biogeochemical processes that produce a specific sedimentary fingerprint are relevant for biogeochemical (de)oxygenation feedbacks (e.g., denitrification, sedimentary phosphorus and iron release). As a consequence, the sedimentary fingerprints presented in this review cannot only be used to identify OMZ-type biogeochemical cycling in the geological record but also to evaluate whether the extent of reducing conditions in a paleo-environment was amplified or mitigated by biogeochemical 90 feedback mechanisms. Finally, I will identify open questions and future challenges in reconciling observations in modern OMZ-type environments and the paleo-record. 


\section{Biogeochemical cycling in modern OMZs}

\subsection{The influence of ocean circulation on water mass age and oxygen consumption}

Tropical OMZs are laterally fed with central and intermediate water masses that are subducted into the ocean interior at higher latitudes (Sloyan and Rintouil, 2001; Karstensen et al., 2008). Along the flow path of these water masses within the thermocline, degradation of downward sinking organic material drives oxygen consumption and release of remineralized nutrients. Wind-driven upwelling of the oxygendepleted and nutrient-rich water at the eastern ocean boundaries results in high rates of primary and export production as well as further oxygen drawdown in the subsurface. The overall extent of oxygen depletion in eastern boundary OMZs is controlled by the rate of primary production and respiration, both locally and along the flow path, as well as the rate of central and intermediate water formation (Karstensen et al., 2008). The latter is a function of upwelling intensity and climatic conditions in the source regions (Talley, 1993; Karstensen et al., 2008). Water masses within the eastern equatorial Pacific OMZ off Peru have spent approximately 100 to 200 years within the ocean interior (Brandt et al., 2015). During this time, respiratory oxygen consumption has led to a very low or zero oxygen concentration. In comparison, deep water residence time in the Black Sea is considerably longer (literature data range from several hundred to several thousand years) (Murray et al., 1991; Özsoy and Ünlüata, 1997; Algeo and Lyons, 2006), which implies that deep water anoxia can be maintained despite a much lower primary productivity in surface waters ( $130 \mathrm{~g} \mathrm{C} \mathrm{m}^{-2} \mathrm{yr}^{-1}$ ) (Grégoire and Beckers, 2004) compared to the Peruvian upwelling region ( $1300 \mathrm{~g} \mathrm{C} \mathrm{m}^{-2} \mathrm{yr}^{-1}$ ) (Pennington et al., 2006). The Black Sea is characterized by density stratification and an estuarine circulation pattern related to a positive freshwater balance where continental run-off and precipitation exceed evaporation. Since the basin's sill at the Bosporus straits is located above the layer with the highest density gradient (pycnocline), deep water exchange is highly restricted. Moreover, the stable density stratification limits upward mixing of nutrient-replete deep waters into the photic zone. Therefore, biogeochemical feedbacks, which may modulate the intensity and expansion of open-marine OMZs, are less likely to establish in the Black Sea or other semi-restricted euxinic basins.

\subsection{Water column biogeochemistry and benthic-pelagic coupling}

\subsubsection{Nitrogen and manganese}

The most pronounced OMZs of the modern ocean are located in the northeast and southeast equatorial Pacific, the Arabian Sea and the Benguela upwelling system off the coast of Namibia (Paulmier and Ruiz-Pino, 2009). In these ocean regions, oxygen has been drawn down to very low levels and 
organic carbon degradation in the $\mathrm{OMZ}$ is partly mediated by reduction of nitrate $\left(\mathrm{NO}_{3}^{-}\right)$to nitrite $\left(\mathrm{NO}_{2}{ }^{-}\right)$ and gaseous nitrogen compounds $\left(\mathrm{N}_{2} \mathrm{O}, \mathrm{N}_{2}\right)$ (Fig. 1A) (Gruber and Sarmiento, 1997; Lam and Kuypers,

125 2011). In addition to this heterotrophic pathway called denitrification, $\mathrm{NO}_{2}{ }^{-}$is also reduced to $\mathrm{N}_{2}$ by the chemolithoautotrophic anammox process (anaerobe ammonia oxidation) (Daalsgaard et al., 2003; Kuypers et al., 2005; Hammersley et al., 2007). Oxygen measurement with highly sensitive electrochemical sensors in the core of the Peruvian and Chilean OMZs suggest that denitrification is only possible at oxygen concentration below $\sim 50 \mathrm{nM}$ (Thamdrup et al., 2012). Since $\mathrm{N}_{2}$ is unavailable to nonnitrogen fixing primary producers, denitrification and anammox represent the ultimate sink for bioavailable (fixed) nitrogen in the ocean (Gruber, 2008). As a result of partial denitrification and as a biogeochemical signature of nitrate-reducing or 'nitrogenous' conditions, $\mathrm{NO}_{2}$ - accumulates in the water column of (essentially) anoxic OMZs (Fig. 1B).

Bacterial reduction of manganese $(\mathrm{Mn})$ oxide minerals, the pathway following denitrification in the natural succession of organic carbon degradation processes, also takes place in the water column of anoxic OMZs (Fig. 1). From a water column perspective, it is generally difficult to differentiate in situ Mn oxide reduction and dissolution in the lower water column from sedimentary sources (Hawco et al., 2016). However, surface sediments in anoxic OMZs are strongly depleted in Mn relative to the lithogenic background (Böning et al., 2004; Brumsack, 2006) suggesting that much of the Mn loss must take place

140 prior to deposition. Consistent with this notion, pore water Mn concentrations and dissolved Mn fluxes across the sediment-water interface in OMZs are too low as to account for the extent of sedimentary Mn depletion (Scholz et al., 2011) and water column observations (Johnson et al., 1992, 1996). Much of the $\mathrm{Mn}$ that is reductively dissolved in the water column is efficiently transported offshore within the OMZ (Klinkhammer and Bender, 1980; Lewis and Luther, 2000) and contributes to Mn accumulation in the deep ocean (Koschinsky and Halbach, 1995; Klinkhammer et al., 2009).

\subsubsection{Iron and sulfur}

Surface sediments in OMZs are characterized by maxima in pore water $\mathrm{Fe}^{2+}$ at or very close to the sediment water interface (Fig. 1B) (Van der Weijden, 1999; Severmann et al., 2010; Noffke et all., 2012). The dissolved $\mathrm{Fe}^{2+}$ in the 'ferruginous' pore water is derived from the reductive dissolution of $\mathrm{Fe}$ 150 (oxyhydr)oxide minerals by dissimilatory Fe reduction and abiotic Fe reduction with hydrogen sulfide $\left(\mathrm{H}_{2} \mathrm{~S}\right)$ (Canfield, 1989). Due to the absence of oxygen in the bottom water and surface sediment, pore water $\mathrm{Fe}^{2+}$ can be transported across the sediment-water interface by molecular diffusion without being re-oxidized and -precipitated (Fig. 1). The benthic Fe efflux generally increases with decreasing bottom water oxygen concentration and increasing organic carbon rain rate (McManus et al., 1997; Elrod et al., 
2004; Severmann et al., 2010; Noffke et al., 2012), because these parameters control the extent of Fe reoxidation and the intensity of anaerobic microbial metabolism (actual release of Fe from organic material is negligible) (Dale et al., 2015). Due to this general relationship, benthic Fe fluxes tend to decrease from the productive shelf and upper slope in an offshore direction and towards greater water depth (Fig. 1A) (Noffke et al., 2012; Scholz et al., 2016). Due to sedimentary Fe release, OMZ waters are characterized by elevated concentrations of dissolved $\mathrm{Fe}^{2+}$ (tens of $\mathrm{nM}$ ) compared to well-oxygenated coastal water (Fig. 1B) (e.g., Landing and Bruland, 1987; Bruland et al., 2005; Vedamati et al., 2014). In contrast to Mn, however, only a small portion of the reduced Fe is stabilized and transported offshore within the OMZ. This iron is presumably in colloidal form and bound to organic ligands, which allows it to be transported over longer distances (Lohan and Bruland, 2008; Kondo and Moffet, 2015). The remaining Fe is reprecipitated and -deposited close to the sedimentary source. Re-oxidation and scavenging of sedimentderived $\mathrm{Fe}^{2+}$ in the anoxic $\mathrm{OMZ}$ off Peru has been attributed to nitrate-dependent Fe oxidation (Scholz et al., 2016; Heller et al., 2017). In this process, dissolved $\mathrm{Fe}^{2+}$ is oxidized with $\mathrm{NO}_{3}{ }^{-}$as the terminal electron acceptor, either coupled to the microbial reduction of $\mathrm{NO}_{3}{ }^{-}$(Straub et al., 1996; Raiswell and Canfield, 2012) or to an abiotic reduction of $\mathrm{NO}_{2}$ catalyzed by the reactive surfaces of $\mathrm{Fe}$ (oxyhydr)oxide minerals

170 (Picardal, 2012; Klüglein and Kappler, 2013). As evidenced by high sedimentary Fe fluxes and elevated Fe concentrations in the nitrogenous bottom water of OMZs, nitrate-dependent Fe oxidation (and any other Fe scavenging process in OMZs) is relatively inefficient in demobilizing sediment-derived Fe compared to re-oxidation with oxygen. Therefore, reducible Fe can be continuously cycled between the surface sediment and overlying water through oxidation, deposition and dissolution until a fraction of it is retained in the sediment and buried (Fig. 1A) (Scholz et al., 2014b; Scholz et al., 2016). Sedimentary Fe enrichments in the oxic-anoxic transition area at the lower boundary of the Peruvian OMZ indicate that much of the Fe released from shelf and slope sediments eventually accumulates farther downslope where oxygen and nitrate penetrate into the sediment thus preventing further Fe release (Fig. 1A) (Scholz et al., 2014b, c).

Iron (oxyhydr)oxides minerals scavenge phosphate $\left(\mathrm{PO}_{4}{ }^{3-}\right)$ and other particle-reactive compounds (e.g., trace metals) in the water column. Therefore, reductive Fe dissolution and release from $\mathrm{OMZ}$ sediments is generally accompanied by $\mathrm{PO}_{4}{ }^{3-}$ release (McManus et al., 1997; Noffke et al., 2012). Sedimentary $\mathrm{Fe}$ and $\mathrm{PO}_{4}{ }^{3-}$ release (phosphorous is released from both $\mathrm{Fe}$ (oxyhydr)oxides and organic material) support primary productivity in upwelling regions (Johnson et al., 1999; Bruland et al., 2005) and are major sources of dissolved $\mathrm{Fe}$ and $\mathrm{PO}_{4}{ }^{3-}$ to the global ocean (Wallmann et al., 2010; Dale et al., 2015). 
Bacterial sulfate reduction is the dominant pathway of organic matter degradation in $\mathrm{OMZ}$ sediments (Thamdrup and Canfield, 1996; Bohlen et al., 2011). Since any $\mathrm{H}_{2} \mathrm{~S}$ produced immediately reacts with dissolved Fe and reactive Fe (oxyhydr)oxide minerals, $\mathrm{H}_{2} \mathrm{~S}$ does not accumulate in the pore water before these highly reactive Fe phases (i.e., highly reactive towards $\mathrm{H}_{2} \mathrm{~S}$ ) have been completely converted to pyrite $\left(\mathrm{FeS}_{2}\right)$ or metastable sulfide minerals (Canfield, 1989; Canfield et al., 1992). In addition, $\mathrm{H}_{2} \mathrm{~S}$ concentrations in surface sediments of OMZs are kept at a low level by sulfide-oxidizing, nitrate-reducing bacteria such as Thioploca and Thiomargarita (Ferdelman et al., 1997; Schulz et al., 1999). Some of these microorganisms form filaments that are used to actively transport $\mathrm{NO}_{3}{ }^{-}$into the sediment for $\mathrm{H}_{2} \mathrm{~S}$ oxidation (Fossing et al., 1995).

A number of studies have reported plumes of $\mathrm{H}_{2} \mathrm{~S}$ (up to a few tens of $\mu \mathrm{M}$ ) in the water column of the Peruvian and Namibian OMZs (Schunck et al., 2013; Brüchert et al., 2003). On the Peruvian continental margin, sulfidic events coincided with high productivity and water column stagnation following the main upwelling season. Under such conditions, $\mathrm{NO}_{3}{ }^{-}$and $\mathrm{NO}_{2}{ }^{-}$, which normally oxidize $\mathrm{H}_{2} \mathrm{~S}$ in the surface

200 sediment, become depleted in the bottom water so that $\mathrm{H}_{2} \mathrm{~S}$ can escape into the water column (Fig. 1A, Fig. 3) (Sommer et al., 2016). Because of the high solubility of $\mathrm{Fe}^{2+}$ in weakly sulfidic water (Rickard, 2006), sulfidic events in the Peruvian $\mathrm{OMZ}$ are accompanied by exceptionally high dissolved $\mathrm{Fe}^{2+}$ concentrations in the water column (up to hundreds of nM) (Fig. 3) (Scholz et al., 2016). Chemolithoautotrophic sulfide oxidation with $\mathrm{NO}_{3}{ }^{-}$or other nitrogen compounds (Schunck et al., 2013)

205 and nitrate-dependent Fe oxidation (Scholz et al., 2016) likely remove dissolved $\mathrm{H}_{2} \mathrm{~S}$ and $\mathrm{Fe}^{2+}$ at the boundaries of the plume.

\subsubsection{Trace metals}

The goal of this section is to provide a general overview about different modes of trace metal delivery and fixation in OMZ sediments. Therefore, I will focus on metals that are well characterized using data 210 for sediments, pore waters and particulate matter. For detailed reviews of trace metal cycling in the context of ocean anoxia the reader is referred to Brumsack (2006) and Tribovillard et al. (2006).

Arguably the best studied and most frequently used trace metals in the context of ocean anoxia and paleo-redox conditions are vanadium (V), molybdenum (Mo) and uranium (U). These metals have a long residence time (several tens to hundreds thousands of years) and largely uniform concentration in open215 ocean seawater ( $V$ is somewhat depleted in the surface ocean) but are generally enriched in anoxic sediments (Tribovillard et al., 2006). Traditionally, it was argued that V, Mo and $U$ accumulate in OMZ sediments by downward diffusion from the bottom water (Böning et al., 2004; Brumsack, 2006). Such a 
scenario of trace metal accumulation requires a downward directed concentration gradient from the bottom water to the sediment depth of metal removal. This type of pore water profile is common for $U$

220 but rather atypical for V and Mo (Barnes and Cochran, 1990; Klinkhammer and Palmer, 1991; Zheng et al., 2000; McManus et al., 2005; Morford et al., 2005; Scholz et al., 2011). In agreement with this observation, solid phase mass accumulation rates of $U$ are broadly consistent with benthic fluxes (Klinkhammer and Palmer, 1991; McManus et al., 2005). By contrast, sedimentary mass accumulation rates of $\mathrm{V}$ and Mo in anoxic OMZs (Böning et al., 2004; Scholz et al., 2011) are generally higher than 225 expected based on estimates of downward diffusion from the bottom water (Scholz et al., 2017). This observation implies that sedimentary $\mathrm{V}$ and Mo enrichments require a solid carrier phase that delivers these elements to the seafloor. Consistent with this notion, many pore water profiles of $V$ and Mo in OMZs are characterized by surficial maxima indicating that $\mathrm{V}$ and Mo are released from solid carriers during early diagenesis (Zheng et al., 2000; Scholz et al., 2011). Release of V and Mo into the pore water 230 drives an upward directed diffusive flux across the sediment-water interface as well as a downward directed flux into the zone of metal removal (Scholz et al., 2017). Shallow V and Mo peaks in the pore water often coincide with the accumulation of dissolved Fe (and sometimes $\mathrm{Mn}$ ) suggesting that $\mathrm{Fe}$ (oxyhydr)oxides adsorb particle-reactive metals in the water column and 'shuttle' them to the sediment surface (Shaw et al., 1990; Zhang et al., 2000; Scholz et al., 2011). Such a scenario is supported by 235 laboratory experiments (Chan and Riley, 1966a, b) and water column observations showing that $\mathrm{V}$ and Mo are associated with Fe-rich particles in the anoxic and nitrogenous water column of the Peruvian OMZ (Scholz et al., 2017; Ho et al., 2018). Downward sinking organic material is likely to be another important carrier phase for V, Mo and U (Fig. 1A) (e.g., Nameroff et al., 2002; Zheng et al. 2002; Ohnemus et al., 2017, Ho et al., 2018). However, it is not known how much of the metals bound to 240 organic material is actively incorporated by organisms and how much is passively scavenged in the anoxic water column.

The efficiency of the removal mechanism from pore water determines the magnitude of diffusive delivery $(U)$ and the extent to which metals delivered by solid carriers are retained and buried or lost to the water column by diffusion across the sediment-water interface ( $V$ and Mo). The removal of $U$ from 245 pore water is mediated by reduction of $U(V I)$ to $U(I V)$ and precipitation of $U(I V)$ oxides or adsorption to reactive surfaces (Tribovillard et al., 2006). Since $U$ reduction can be mediated by Fe-reducing bacteria (Lovley et al., 1991), diffusive $U$ accumulation in the sediment is favored in depositional settings where Fe reduction takes place close to the sediment surface (McManus et al., 2005). The mechanism(s) leading to $\mathrm{V}$ precipitation in anoxic sediments are not well characterized. It is generally believed that $\mathrm{V}$ 
250 reduction $(\mathrm{V}(\mathrm{V})$ to $\mathrm{V}(\mathrm{IV})$ to $\mathrm{V}(\mathrm{III}))$ and removal is induced under anoxic (i.e., ferruginous) but not necessarily sulfidic conditions in the pore water (Emerson and Huested, 1991; Wehrli and Stumm, 1989; Wanty and Goldhaber, 1992; Tribovillard et al., 2006). In contrast, Mo removal from pore water into sulfurized organic molecules and pyrite or other Fe sulfide compounds requires the presence of dissolved $\mathrm{H}_{2} \mathrm{~S}$ (Helz et al., 1996; Erickson and Helz, 2000; Tribovillard et al., 2004; Vorlicek et al., 2018).

\section{2.3. Comparison to biogeochemical cycling in the euxinic Black Sea}

All of the biogeochemical processes taking place in the water column and sediments of OMZs (Fig. 1) are observed in the euxinic Black Sea as well (Fig. 2). However, the location (e.g., sediment and pore water versus water column) and water depth where they take place is different, which has important implications for the dynamics of nutrient turnover, primary production and respiratory oxygen consumption.

In the Black Sea, oxygen is depleted within the uppermost $70 \mathrm{~m}$ and the nitrogenous zone is located between $\sim 70$ and $100 \mathrm{~m}$ water depth (Fig. 2B) (Friederich et al., 1990; Kuypers et al., 2003). Below the depth of $\mathrm{NO}_{3}{ }^{-}$and $\mathrm{NO}_{2}{ }^{-}$depletion, organic carbon degradation is chiefly mediated by bacterial sulfate reduction and $\mathrm{H}_{2} \mathrm{~S}$ concentrations increase up to about $400 \mu \mathrm{M}$ within the deep water. Elevated $\mathrm{Fe}^{2+}$ 265 concentrations up to $300 \mathrm{nM}$ (i.e., comparable to those in the sulfidic plumes in the Peruvian OMZ) (Fig. 1B) are observed within the weakly sulfidic layer between 100 and $200 \mathrm{~m}$ water depth (Fig. 2B). Below this depth, dissolved Fe concentrations are capped by the solubility of Fe sulfide minerals such as mackinawite $(\mathrm{FeS})$ and greigite $\left(\mathrm{Fe}_{3} \mathrm{~S}_{4}\right)$ (Lewis and Landing, 1991).

Similar to sediments in OMZs, anoxic shelf sediments in the Black Sea release Fe to the water column

270 (Wijsman et al., 2001). Most of this sediment-derived Fe is re-precipitated in the oxic bottom water, but a small part is transported offshore, presumably in colloidal form or stabilized by organic ligands (Raiswell and Canfield, 2012). Once trapped within the anoxic deep water, shelf-derived Fe cannot escape to shallower areas anymore since the basin is capped by nitrogenous and oxic water masses, which efficiently oxidize any Fe that is transported in a vertical direction by diffusion or advection (Fig. 2).

275 In fact, water column profiles of $\mathrm{Fe}^{2+}, \mathrm{NO}_{3}{ }^{-}$and $\mathrm{NO}_{2}$ suggest that much of the $\mathrm{Fe}$ trapping could be mediated by nitrate-dependent Fe oxidation (Scholz et al., 2016) rather than oxidation with oxygen (Fig. 2B). Due to the oxidative barrier overlying the Black Sea deep water, concentrations of Fe and $\mathrm{Mn}$ (and also $\mathrm{PO}_{4}{ }^{3-}$ ) (Dellwig et al., 2010) rise to appreciable levels until the solubility products of authigenic minerals are exceeded. An important implication of this trapping mechanism is that, in contrast to upwelling-related OMZs, nutrients are retained in the deep water and/or buried in the basin sediments 
rather than recycled and transported into the photic zone by coastal upwelling. Therefore, primary productivity in the pelagic Black Sea is controlled by external nutrient inputs from rivers and shelf sources (Grégoire and Beckers, 2004) whereas in OMZs upwelling of thermocline water (Pennington et al., 2006) and redox-dependent nutrient recycling from anoxic shelf sediments supply most of the nutrients to the productive surface ocean (Johnson et al., 1999; Bruland et al., 2005; Dale et al., 2017). Due to the proximity and mutual dependency of sedimentary nutrient sources and sinks, primary productivity and respiration, the intensity and expansion of OMZs can be amplified or mitigated by benthic-pelagic feedback mechanisms.

\subsection{Amplification or mitigation of anoxia by benthic-pelagic feedbacks}

According to conventional theory, the extent of reducing conditions in OMZs is bounded by a negative feedback within the nitrogen cycle (Canfield, 2006; Ulloa et al., 2012). Once oxygen is depleted, denitrification and anammox within the nitrogenous zone decrease the size of the bioavailable $\mathrm{NO}_{3}{ }^{-}$pool. Upon upwelling of these waters, primary production becomes nitrogen-limited, which results in a reduction in carbon export. Reduced export production, in turn, reduces the rate of respiration in $\mathrm{OMZ}$ waters (including denitrification) thus reducing the oxygen and $\mathrm{NO}_{3}{ }^{-}$demand and preventing further OMZ intensification (Fig. 4A). According to Canfield (2006), this denitrification feedback prevents $\mathrm{NO}_{3}{ }^{-}$ and $\mathrm{NO}_{2}{ }^{-}$depletion and therefore the onset of bacterial sulfate reduction, which could eventually drive the $\mathrm{OMZ}$ into euxinic conditions.

Importantly, however, most of the OMZs in the modern ocean are located in high-nutrient-lowchlorophyll (HNLC) regions (eastern equatorial Pacific, Benguela upwelling), which implies that primary productivity and, by inference, respiratory oxygen consumption is limited by Fe rather than $\mathrm{NO}_{3}{ }^{-}$ (Hutchins and Bruland, 1998; Johnson et al., 1999). Given the well-established relationship between bottom water oxygen concentration and sedimentary Fe release (Severmann et al., 2010; Dale et al., 2015), ocean deoxygenation could lead to an increase in Fe supply to the surface ocean in these regions.

305 This would lead to an increase in primary and export production and could therefore cause OMZ intensification in a positive feedback loop (Fig. 4B) (Scholz et al., 2014a). In a related fashion, $\mathrm{PO}_{4}{ }^{3-}$ release from anoxic sediments is thought to amplify marine productivity and ocean anoxia on geological timescales, e.g., during oceanic anoxic events (Ingall and Jahnke, 1994; Van Capellen and Ingall, 1994; Wallmann, 2003).

310 A dynamic interplay of the feedback connections described above could have a strong impact on nutrient and redox cycling in OMZs. Modelling studies suggest that any negative feedback between 
primary production and denitrification in OMZs (Fig. 4A) can be overcome if the bioavailable $\mathrm{NO}_{3}{ }^{-}$pool in the photic zone is continuously replenished by nitrogen fixation (Canfield, 2006). Under such circumstances, sulfate reduction can become the dominant organic matter respiration pathway and $\mathrm{H}_{2} \mathrm{~S}$ can accumulate in the water column (Fig. 4C). Theoretically, nitrogen fixation in OMZs is favored by dissolved nitrogen to $\mathrm{PO}_{4}{ }^{3-}$ ratios below that of non-nitrogen-fixing phytoplankton (N/P < 16) (Redfield, 1963; Tyrell, 1999; Gruber, 2008) related to denitrification and sedimentary phosphorus release. Moreover, sedimentary Fe release can satisfy the tremendous Fe demand of nitrogen-fixing organisms (Fig. 4C) (Falkowski, 1997; Moore and Doney, 2007). Such a scenario is in line with findings in the 320 Peruvian $\mathrm{OMZ}$ where short-lived events of $\mathrm{NO}_{3}{ }^{-}$and $\mathrm{NO}_{2}{ }^{-}$depletion and weakly sulfidic conditions in the water column (Fig. 3) were shown to coincide with intense nitrogen fixation (Löscher et al., 2014) enabled by $\mathrm{Fe}$ and $\mathrm{PO}_{4}{ }^{3-}$ release from the anoxic shelf sediments (Noffke et al., 2012). Whether such feedbacks between the nitrogen, phosphorus and Fe cycles could drive OMZs into permanently euxinic conditions or trigger a transition from continental margin to basin-wide anoxia has yet to be evaluated. It has been hypothesized that substantial accumulation of $\mathrm{H}_{2} \mathrm{~S}$ in the bottom water and surface sediment causes a shutdown of sedimentary Fe release at a certain point, because most of the Fe is converted to pyrite and buried in the sediment (Fig. 4C) (Scholz et al., 2014a). In other words, intensified pyrite formation could turn continental margin sediments from a net source to a net sink for Fe thus cancelling the feedback between sedimentary Fe release, biological productivity and oxidant consumption.

Given the strongly differing residence times of nitrogen, $\mathrm{Fe}$ and phosphorus in the ocean (fixed nitrogen: $\sim 10^{3}$ years; Fe: $\sim 10^{2}$ years; $\mathrm{PO}_{4}^{3-}: ~ \sim 10^{4}$ years) (Gruber, 2008; Wallmann, 2010; Boyd and Ellwood, 2010), feedback connections among their biogeochemical cycles are likely to unfold on longer timescales. Biogeochemical modeling in the context of past oceanic anoxic events can be a powerful tool to evaluate the role of benthic-pelagic feedbacks in modulating OMZ expansion and intensity. However,

335 for ground truthing purposes any paleo-modeling needs to be informed by paleo-proxy records. The following discussion of proxy signatures of OMZ-type biogeochemical cycling is meant to provide a framework for the reconstruction of biogeochemical feedbacks in OMZ-like paleo-settings.

\section{Sedimentary fingerprint of OMZ-type biogeochemical cycling}

\subsection{Iron-based paleo-proxies}

Enrichments of reactive $\mathrm{Fe}$ in marine sediment and sedimentary rocks are generally regarded as a paleo-indicator for anoxic conditions in the water column at the time of deposition. This rationale is related to observations in the modern Black Sea (Fig. 5B) where sediments are characterized by highly 
reactive $\mathrm{Fe}\left(\mathrm{Fe}_{\mathrm{HR}}\right)$ to total $\mathrm{Fe}$ ratios $\left(\mathrm{Fe}_{\mathrm{HR}} / \mathrm{Fe}_{\mathrm{T}}\right)>0.38$, which is used as a threshold to indicate anoxia (Raiswell and Canfield, 1998; Poulton and Canfield, 2011). These enrichments, along with elevated Fe to 345 aluminum (Al) ratios relative to the lithogenic background, are generated by Fe release from shelf sediments and Fe trapping in the euxinic basin, a mechanism referred to as "shelf-to-basin Fe shuttle" (Raiswell and Anderson, 2005; Lyons and Severmann, 2006). Due to sulfidic conditions within the water column and sediments, most of the reactive Fe supplied from the surrounding shelf areas is converted to pyrite. Therefore, a high proportion of pyrite $\mathrm{Fe}\left(\mathrm{Fe}_{\mathrm{py}}\right)$ within the $\mathrm{Fe}_{\mathrm{HR}}$ pool is considered to be a paleo-

350 indicator for euxinic conditions $\left(\mathrm{Fe}_{\mathrm{py}} / \mathrm{Fe}_{\mathrm{HR}}>0.8\right.$ is used as a threshold for euxinia) (Raiswell et al., 1997; Poulton and Canfield, 2011). Highly reactive Fe (sum of Fe (oxyhydr)oxide, Fe carbonate and pyrite) is recovered from bulk sediment by wet chemical extraction techniques (Canfield et al., 1986; Poulton and Canfield, 2005). These observations are the framework upon which a triad of Fe-based paleo-proxies $\left(\mathrm{Fe}_{\mathrm{HR}} / \mathrm{Fe}_{\mathrm{T}}, \mathrm{Fe}_{\mathrm{T}} / \mathrm{Al}, \mathrm{Fe}_{\mathrm{py}} / \mathrm{Fe}_{\mathrm{HR}}\right)$ is widely used to track anoxia in the geological record, including in openmarine settings. However, I suggest here that the interpretation of these proxies in open-marine settings will differ because of differences in the geological and biogeochemical factors that underpin Fe mobilization and deposition.

\subsubsection{Observations in modern OMZs}

In the context of OMZs, associating anoxia with sedimentary Fe enrichments is problematic. Surface sediments in OMZs are ferruginous, which implies that reactive Fe can be mobilized and transported across the sediment-water interface (see Section 2.2.2.). Provided that bottom currents transport the dissolved Fe away from the source area, one would expect the remaining sediment to be become depleted rather than enriched in highly reactive Fe. By contrast, re-deposition of the transported Fe at another location, e.g., due to re-oxidation with $\mathrm{NO}_{3}{ }^{-}, \mathrm{NO}_{2}{ }^{-}$or oxygen in the water column, and retention as pyrite in the sediment would generate an enrichment of highly reactive Fe in the sink area. Depending on the size and distance between source and sink areas and the transport capacity for Fe within the OMZ waters, Fe redistribution across the continental margin would yield a complex pattern of sedimentary Fe enrichments and depletions. Consistent with this scenario, shelf sediments within the Peruvian OMZ are slightly enriched in reactive Fe whereas slope sediment within the $\mathrm{OMZ}$ are depleted in highly reactive Fe compared to continental margin sediments with oxic bottom water (Fig. 5A) (Scholz et al., 2014b, c). Due to intense sulfate reduction within the sediment, pyrite is the principle burial phase for reactive Fe throughout the Peruvian OMZ (Suits and Arthur, 2000; Scholz et al., 2014a). Slope sediments underlying the lower boundary of the $\mathrm{OMZ}$ are characterized by elevated $\mathrm{Fe}_{\mathrm{T}} / \mathrm{Al}$, which has been attributed to a net supply of highly reactive Fe from farther upslope. Because slope sediments below the Peruvian OMZ are 
375 non-sulfidic (Scholz et al., 2011) much of the reactive Fe (oxyhydr)oxide delivered is converted to authigenic silicate minerals (e.g., glauconite), consisting of both ferrous and ferric Fe, during early diagenesis (Suits and Arthur, 2000; Böning et al., 2004; Scholz et al., 2014c). As silicate Fe is not efficiently dissolved by conventional chemical extraction techniques for the recovery of highly reactive Fe (e.g., Poulton and Canfield, 2005), sediments below the OMZ display highly elevated $\mathrm{Fe}_{\mathrm{T}} / \mathrm{Al}$ ratios but inconspicuous $\mathrm{Fe}_{\mathrm{HR}} / \mathrm{Fe}_{\mathrm{T}}$ ratios (Scholz et al., 2014c). Authigenic glauconite has been observed at the boundaries of other OMZs (Mullins et al., 1985) and, interestingly, the conditions leading to the precipitation of this mineral are similar to those leading to the formation of greenalite (Harder, 1980; Tosca et al., 2016), the predominant Fe silicate mineral in Precambrian banded iron formations (Bekker et al, 2010).

\subsubsection{Theoretical framework for the interpretation of iron-based paleo-proxies in the context of OMZs}

The distributions of highly reactive Fe phases in modern OMZs are rather complex compared to euxinic basins where the source and sink areas are clearly separated from each other (Raiswell and Anderson, 2005; Scholz et al., 2014b). To interpret long-term proxy records of $\mathrm{Fe}_{\mathrm{HR}} / \mathrm{Fe}_{\mathrm{T}}$ or $\mathrm{Fe}_{\mathrm{T}} / \mathrm{Al}$ at a single location within or adjacent to an OMZ, a systematic framework of how geological factors 390 (sedimentation rate, continental margin geometry relative to the water column redox structure) control the extent of sedimentary Fe enrichment or depletion is required.

In Fig. 6A and Fig. 6B, indices for sedimentary Fe enrichment and anoxia $\left(\mathrm{Fe}_{\mathrm{T}} / \mathrm{Al}, \mathrm{Fe}_{\mathrm{HR}} / \mathrm{Fe}_{\mathrm{T}}\right)$ are plotted against benthic Fe effluxes and authigenic (i.e., non-lithogenic) Fe rain rates. At higher background sedimentation of terrigenous $\mathrm{Fe}$ and $\mathrm{Al}$, Fe release or trapping has a smaller impact on $\mathrm{Fe}_{\mathrm{T}} / \mathrm{Al}$ or $\mathrm{Fe}_{\mathrm{HR}} / \mathrm{Fe}_{\mathrm{T}}$

395 than in a scenario where little terrigenous material is delivered (Raiswell and Anderson, 2005). To account for this effect, I computed scenarios of reactive Fe release or trapping with different sediment mass accumulation rates (MARs) (Fig. 6). The benthic Fe effluxes and MARs applied in these calculations cover the typical range of values observed in the modern ocean (Burdige, 2007; Dale et al., 2015). As no literature data for authigenic Fe rain rates are available, the range of published benthic Fe effluxes was

400 adopted for this parameter as well (with reverse sign). The validity of this approach is demonstrated by the values of $\mathrm{Fe}_{\mathrm{T}} / \mathrm{Al}$ and $\mathrm{Fe}_{\mathrm{HR}} / \mathrm{Fe}_{\mathrm{T}}$ obtained in the different scenarios of reactive Fe trapping, which are consistent with published data for modern euxinic basins and paleo-records (e.g., Raiswell and Canfield, 1998; Lyons and Severmann, 2006; Poulton et al., 2010). The starting value for each scenario of reactive Fe release or trapping is the $\mathrm{Fe}_{\mathrm{T}} / \mathrm{Al}$ of the average upper continental crust (0.44) (McLennan, 2001) and 405 the $\mathrm{Fe}_{\mathrm{HR}} / \mathrm{Fe}_{\mathrm{T}}$ of continental margin sediments with oxic bottom water (0.28 \pm 0.06$)$ (Poulton and Raiswell, 2002). All scenarios as well as $\mathrm{Fe}_{\mathrm{T}} / \mathrm{Al}$ and $\mathrm{Fe}_{\mathrm{HR}} / \mathrm{Fe}_{\mathrm{T}}$ data for sediments from the Peruvian continental 
margin, the Gulf of California and the Black Sea are plotted in a diagram of $\mathrm{Fe}_{\mathrm{T}} / \mathrm{Al}$ versus $\mathrm{Fe}_{\mathrm{HR}} / \mathrm{Fe}_{\mathrm{T}}$ in Fig. 6C (a close-up highlighting OMZ data is shown in Fig. 6D).

The generalized modeling scenarios reveal that reactive Fe release and trapping theoretically results 410 in $\mathrm{Fe}_{\mathrm{T}} / \mathrm{Al}$ and $\mathrm{Fe}_{\mathrm{HR}} / \mathrm{Fe}_{\mathrm{T}}$ values that lie on one single trend line (Fig. $6 \mathrm{C}$ ). The mass accumulation of terrigenous sediment determines the extent of deviation from the starting value at a given authigenic Fe rain rate or benthic Fe efflux. Most of the data plotted in Fig. 6C and Fig. 6D plot along this trend line, which corroborates that redistribution of reactive Fe is responsible for the observed variability. Slope sediments in the Peruvian $\mathrm{OMZ}$ are characterized by lower $\mathrm{Fe} / \mathrm{T} / \mathrm{Al}$ and $\mathrm{Fe}_{\mathrm{HR}} / \mathrm{Fe}_{\mathrm{T}}$ compared to the starting 415 value (Fig. 6C and D). Typical MARs on the Peruvian slope are of the order of $0.01-0.05 \mathrm{~g} \mathrm{~cm}^{-2} \mathrm{yr}^{-1}$ (Scholz et al., 2011). To generate the observed deviation in $\mathrm{Fe}_{\mathrm{T}} / \mathrm{Al}$ and $\mathrm{Fe}_{\mathrm{HR}} / \mathrm{Fe}_{\mathrm{T}}$ from the starting value at this MAR, a benthic efflux of $\sim 1 \mu \mathrm{mol} \mathrm{cm} \mathrm{yr}^{-1}$ is required. This estimate is in good agreement with the range of benthic Fe fluxes observed in the same area $\left(0.3-3.2 \mu \mathrm{mol} \mathrm{cm}^{-2} \mathrm{yr}^{-1}\right)$ (Noffke et al., 2012) suggesting that, indeed, sedimentary Fe release has caused the observed depletion in reactive Fe (Scholz

420 et al., 2014b). Deviations from the trend line in Fig. $6 \mathrm{C}$ towards higher $\mathrm{Fe}_{\mathrm{HR}} / \mathrm{Fe}_{\mathrm{T}}$ can be generated by pyritization of Fe bound to silicate minerals, e.g., due to a long-term exposure of clay minerals to $\mathrm{H}_{2} \mathrm{~S}$ (Raiswell and Canfield, 1996). Conversely, delivery of reactive Fe and precipitation of authigenic Fe silicate minerals would generate a shift towards lower $\mathrm{Fe}_{\mathrm{HR}} / \mathrm{Fe}_{\mathrm{T}}$ and higher $\mathrm{Fe}_{\mathrm{T}} / \mathrm{Al}$. Consistent with this scenario, sediments below the Peruvian OMZ, which have been shown to be enriched in Fe silicate 425 minerals, plot on the corresponding trend line (Fig. 6C) (Scholz et al, 2014c).

In general, elevated $\mathrm{Fe}_{\mathrm{T}} / \mathrm{Al}$ and $\mathrm{Fe}_{\mathrm{HR}} / \mathrm{Fe}_{\mathrm{T}}>0.38$ require either a high authigenic Fe rain rate or a low rate of terrigenous background sedimentation (Fig. 6). Taking the threshold for anoxia as a reference value, the modest deviations in $\mathrm{Fe}_{\mathrm{HR}} / \mathrm{Fe}_{\mathrm{T}}$ observed in the OMZs off Peru and in the Gulf of California (Fig. 6C) would not be indicative of anoxic conditions in the bottom water. Importantly, however, these 430 continental margin environments are characterized by a one to two order of magnitude higher MAR (Calvert et al., 1966; Scholz et al., 2011) compared to the pelagic Black Sea (MAR: $<0.005 \mathrm{~g} \mathrm{~cm}^{-2} \mathrm{yr}^{-1}$ ) (Brumsack, 1989; Calvert et al., 1991). Taking this difference in MAR into account reveals that sediments in these systems receive a similar supply of authigenic Fe as pelagic Black Sea sediments (compare dark blue and greenish lines in Fig. $6 \mathrm{~A}$ and Fig. 6B). Applying one single threshold of $\mathrm{Fe}_{\mathrm{HR}} / \mathrm{Fe}_{\mathrm{T}}$ for anoxia in a 435 broad range of depositional environments seems questionable in this context. To account for this problem, Poulton and Canfield (2011) suggested that $\mathrm{Fe}_{\mathrm{HR}} / \mathrm{Fe}_{\mathrm{T}}$ between 0.22 and 0.38 can also be indicative for anoxia if terrigenous background sedimentation is high. However, this transitional range is entirely consistent with the average $\mathrm{Fe}_{\mathrm{HR}} / \mathrm{Fe}_{\mathrm{T}}$ of continental margin sediments with oxic bottom water 
(Poulton and Raiswell, 2002). The trend line of $\mathrm{Fe}_{\mathrm{T}} / \mathrm{Al}$ versus $\mathrm{Fe}_{\mathrm{HR}} / \mathrm{Fe}_{\mathrm{T}}$ in Fig. $6 \mathrm{C}$ can provide additional 440 constraints on whether a Fe proxy signature can be assigned to sedimentary Fe release and trapping. It should be noted, however, that trapping of Fe from other non-lithogenic sources (i.e., hydrothermal venting) is expected to generate enrichments that plot on the same trend line.

On open-marine continental margins, the balance between reactive Fe source and sink areas likely depends on a combination of biogeochemical and sedimentological factors. The OMZ in the Gulf of

445 California is located between 400 and 800 m water depth (Campbell and Gieskes, 1984). Due to the sheltered character and semi-restricted bathymetry of the Gulf of California, Fe released from shelf and upper slope sediments can be transported downslope and accumulate within and below the OMZ. By contrast, the Peru OMZ is located at shallower depth (below 50-100 m water depth) and sedimentary Fe release takes place in a dynamic shelf environment where strong bottom currents can transport

450 sediment-derived solutes in an alongshore direction (Suess et al., 1987). Local enrichments in reactive Fe are likely to form in organic carbon depocenters (Reimers and Suess, 1983) where shallow pyrite formation (Scholz et al, 2014a) is supported by intense bacterial sulfate reduction in the surface sediment (Bohlen et al., 2011). Sediments on the upper slope within the Peruvian OMZ are frequently resuspended by internal waves (Mosch et al., 2012), which causes comparably low net sedimentation rates

455 (Scholz et al, 2011) and creates a favorable environment for sedimentary Fe depletion. Downward focusing of sediment-derived Fe from the upper slope into the oxic sink area with less dynamic sediment transport regime causes Fe accumulation in a relatively confined area close to the lower boundary of the OMZ (Scholz et al., 2014b).

Considering the small-scale variability in sedimentological factors on the Peruvian continental margin, 460 a laterally consistent enrichment in reactive Fe like in the Black Sea is unlikely to evolve. By contrast, in a less dynamic environment such as the Gulf of California continental slope, widespread Fe enrichments may develop, provided that background sedimentation does not overwhelm the authigenic Fe rain rate. In both continental margin environments spatial (modern surface sediments) or temporal (in a paleorecord) variability in $\mathrm{Fe}_{\mathrm{T}} / \mathrm{Al}$ and $\mathrm{Fe}_{\mathrm{HR}} / \mathrm{Fe}_{\mathrm{T}}$ along the trend lines in Fig. $6 \mathrm{C}$ (toward both higher and lower 465 values) is indicative of enhanced Fe mobility in the surface sediment and bottom water. Provided that Fe transport in the water column takes place within reach of the photic zone (e.g., through upwelling like in the Peruvian OMZ), the mobilized Fe can support biological productivity in the surface ocean.

\subsection{Trace metal-based paleo-proxies}


Metals respond in a systematic fashion to the redox gradients observed in the water column and 470 surface sediments of OMZs (Fig. 5A) (Nameroff et al., 2002; Böning et al., 2004, 2005; Scholz et al., 2011). Because of reductive $\mathrm{Mn}$ dissolution and offshore transport in the water column, OMZ sediments are commonly depleted in Mn relative to lithogenic material (Böning et al., 2004, 2005; Borchers et al., 2005). By contrast, in euxinic basins Mn supplied from the surrounding shelf areas is trapped within the basin (Fig. 5B) (Brumsack, 2006; Lyons and Severmann, 2006; Scholz et al., 2013). Sedimentary Mn

475 depletion is not limited to the area where the $\mathrm{OMZ}$ impinges the seafloor but extends farther downslope into areas with well-oxygenated bottom water (Böning et al., 2004, 2005; Scholz et al., 2011). Therefore, $\mathrm{Mn}$ depletion relative to crustal material can generally be indicative of the presence of an anoxic, though not necessarily nitrogenous water mass at an open-marine continental margin (Table 1).

The behavior of many other metals that have been used as a paleo-redox proxy is tied to the redox 480 state of the bottom water and surface sediment (Fig. 5A, Fig. 7). On the Peruvian continental margin, $U$ is the first element to become enriched in the sediment as the oxygen concentrations in the bottom water decrease (Fig. 7). This trend can be explained by $U$ reduction and fixation under ferruginous conditions in the surface sediment. As the bottom water and surface sediments become more reducing, $\mathrm{V}$ and Mo accumulation outpace $U$ accumulation. Sedimentary Mo enrichments reach comparable values to Black 485 Sea sediments (Fig. 7) on the shallow shelf where $\mathrm{H}_{2} \mathrm{~S}$ is detectable shortly below the sediment-water interface (Böning et al., 2004; Scholz et al., 2011). Based on this pattern, Scholz et al. (2004a) suggested that ratios of excess Mo to $U$ (see Electronic Supplement for details on the calculation of excess metal concentrations) can be used in conjunction with Fe speciation data to reconstruct whether surface sediments were oxic, ferruginous or sulfidic at the time of deposition (Table 1, Fig. 7). Differentiating 490 between ferruginous and sulfidic conditions in surface sediment is important for assessing whether conditions were conducive to sedimentary Fe release or Fe trapping, retention and burial as pyrite (Scholz et al., 2014a).

Sedimentary molybdenum concentrations above $25 \mu \mathrm{g} \mathrm{g}^{-1}$ have been suggested to be generally indicative for euxinic conditions (Scott and Lyons, 2012; Dahl et al, 2013). Sediments in the OMZs off 495 Peru and Namibia clearly exceed this threshold (Fig. 6) (Böning et al., 2004; Borchers et al., 2005; Scholz et al., 2011), which has tentatively been attributed to the occurrence of sulfidic events and Mo scavenging from the sulfidic water column (Dahl et al., 2013). However, on the Peruvian continental margin, particulate Mo concentrations within sulfidic water masses are low compared to those in nitrogenous and oxic water masses (Scholz et al., 2017). Based on this observation, Scholz et al. (2017) hypothesized that Mo accumulation in shelf sediments is accelerated by Mo delivery with Fe 
(oxhydr)oxides that precipitate in the water column through nitrate-dependent Fe oxidation. Further research on the distribution, isotope composition and speciation of particulate metals in OMZs will help to better characterize the mode of trace metal scavenging under anoxic conditions.

Recently, Zhang et al. (2016) introduced V depletion relative to terrigenous material as an indicator for weakly oxic conditions in the bottom water at the boundaries of OMZs. This notion was based on observations in the northeast equatorial Pacific off Mexico where sediments below the $\mathrm{OMZ}$ seem to be slightly depleted in V but enriched in Mo relative to lithogenic material (Nameroff et al., 2002). Zhang et al. (2016) attributed this observation to $\mathrm{V}$ release from $\mathrm{Mn}$ oxide minerals under anoxic but non-sulfidic conditions in the surface sediment underlying weakly oxic bottom water. The mechanism of Mo fixation 510 under Mn-reducing and non-sulfidic conditions was not specified by Zhang et al. (2016). In general, the deviations in V concentration from lithogenic material reported by Nameroff et al. (2002) are small. Moreover, $\mathrm{V}$ concentrations in lithogenic material are generally high (almost two orders of magnitude higher than Mo) but can vary considerably as a function of provenance and lithology (McLennan, 2001; Planavsky et al., 2016). As a consequence, small depletions of $V$ relative to a high lithogenic background 515 are associated with a large uncertainty.

Within the oxygen gradient at the lower boundary of the Peruvian OMZ, ratios of excess $\mathrm{V}$ to Mo clearly exceed the V/Mo of the upper continental crust, which implies that under weakly oxic conditions $V$ is more efficiently delivered and/or retained than Mo. This observation is in conflict with the proxy rationale outlined by Zhang et al. (2016) but consistent with the general notion that $\mathrm{V}$ can accumulate 520 under anoxic and non-sulfidic conditions whereas Mo accumulation requires the availability of free $\mathrm{H}_{2} \mathrm{~S}$ (Tribovillard et al., 2006). On the Peruvian continental margin excess V/Mo ratios decrease throughout the redox-gradient in the bottom water and approach the V/Mo of the upper continental crust in sulfidic shelf sediments (Fig. 7). According to this pattern, V/Mo could be applied along with Mo/U to trace the transition from ferruginous to sulfidic conditions in the surface sediment (Table 1).

525 Excess $\mathrm{V}$ concentrations in the Peruvian $\mathrm{OMZ}$ are generally high compared to Black Sea sediments (Fig. 7). This trend could be related to $V$ delivery by Fe (oxyhydr)oxides (Scholz et al. (2017) and/or organic particles originating from the photic zone or the OMZ itself (Ho et al., 2018). Ohnemus et al. (2017) demonstrated that heterotrophic (presumably denitrifying) microbial communities in the Peruvian $\mathrm{OMZ}$ are particularly enriched in $\mathrm{V}$ and other transition metals compared to phototrophic 530 organism at the sea surface. Other nutrient-related trace metals that are poorly soluble under sulfidic conditions (e.g., cadmium (Cd)) are generally enriched in the sediments of productive upwelling areas compared to sediments in euxinic basins (Brumsack, 2006). This trend is even more pronounced when 
nutrient-type trace metals are normalized to Mo. Sweere et al. (2016) demonstrated that ratios of Cd to Mo increase from values close to seawater $(\mathrm{Cd} / \mathrm{Mo}=0.007)$ in restricted basins to values similar to 535 phytoplankton $(\mathrm{Cd} / \mathrm{Mo}=2)($ Brumsack, 1986) in open-marine upwelling regions. Future work comparing the speciation and isotope composition of metals in suspended particulate organic matter and sediments of OMZs may help to identify the specific sedimentary fingerprint of different biological communities (with different enzymes and thus metal quota) and metabolisms in the overlying water column.

\subsection{Tool box for the identification of benthic-pelagic feedbacks in the geological record}

540 Proxy signatures for redox conditions and sedimentary Fe release and trapping $\left(\mathrm{Fe}_{\mathrm{T}} / \mathrm{Al}, \mathrm{Fe}_{\mathrm{HR}} / \mathrm{Fe}_{\mathrm{T}}\right.$, $(\mathrm{Mo} / \mathrm{U})_{\mathrm{xs}}$ ) (Table 1) can be combined with paleo-indicators for sedimentary phosphorus and water column nitrogen cycling to identify OMZ-type biogeochemical cycling and the associated interplay of benthic-pelagic feedbacks (Fig. 4) in the geological record.

Phosphorus is preferentially remineralized from organic material relative to carbon under anoxic 545 conditions in the bottom water (Ingall and Jahnke, 1994, 1997; Wallmann et al., 2010). Therefore, sedimentary $\mathrm{PO}_{4}{ }^{3-}$ release in anoxic ocean regions generates elevated sedimentary carbon to phosphorus ratios (Ingall and Van Cappellen, 1990; Algeo and Ingall, 2007) compared to the average composition of phytoplankton (C/P > 106) (Redfield, 1963). This signature can be used to identify sedimentary phosphorus release in the geological record (Table 1) (März et al., 2008; Mort et al., 2008; Poulton et al.,

550 2015). Conversely, the extent of phosphorus burial with organic material, Fe (oxyhydr)oxides or biogenic and authigenic phosphorus minerals (carbonate fluorapatite, CFA) can be evaluated by a combination of elevated phosphorus to $\mathrm{Al}$ ratios (P/Al) and sedimentary phosphorus speciation (e.g., Schenau and De Lange, 2001; Mort et al., 2008; März et al., 2008; Poulton et al., 2015) (Table 1). In modern OMZs enhanced sedimentary $\mathrm{P} / \mathrm{Al}$ ratios are often observed in slope sediments where low to zero net sedimentation rates and strong bottom currents favor the accumulation of CFA nodules and crusts (Glenn and Arthur, 1988). In this case, elevated P/Al and CFA concentrations are not indicative of enhanced phosphorus burial on a continental margin scale but rather for sediment reorganization and CFA build-up in a confined area.

Nitrogen cycling in the water column (i.e., nitrogen loss under nitrogenous versus nitrogen fixation 560 under euxinic conditions) can be reconstructed by the aid of nitrogen isotopes (Table 1). Denitrification and anammox in the nitrogenous water column leaves the remaining $\mathrm{NO}_{3}{ }^{-}$enriched in the heavy nitrogen isotope $\left({ }^{15} \mathrm{~N}\right)$. If the remaining $\mathrm{NO}_{3}^{-}$is incorporated into phytoplankton biomass and subsequently preserved in the sediments, water column nitrogen loss can be identified in the 
sedimentary record by elevated $\delta^{15} \mathrm{~N}$ values relative to atmospheric nitrogen $\left(\delta^{15} \mathrm{~N}_{\text {sediment }}>0 \%\right.$ ) (Altabet 565 et al., 1995; Ganeshram et al., 2000; Galbraith et al., 2004). Quantitative denitrification, which is a prerequisite for the onset of bacterial sulfate reduction and euxinic conditions in an $\mathrm{OMZ}$, would cancel out any isotope fractionation associated with partial nitrogen loss (Boyle et al., 2013). Under such circumstances, the sedimentary $\delta^{15} \mathrm{~N}$ approaches the nitrogen isotope composition of nitrogen-fixing microorganisms $\left(\delta^{15} \mathrm{~N}_{\text {sediment }} \leq 0 \%\right.$ \%) (see, e.g., Higgins et al., 2012, and Ader et al., 2016, for further 570 details, including the role of ammonia). Importantly, nitrogen isotope ratios have to be interpreted on a relative scale as the regional $\delta^{15} \mathrm{~N}$ is superimposed by the global secular $\delta^{15} \mathrm{~N}$ trend (Algeo et al, 2014). For instance, during Cretaceous oceanic anoxic events, partial water column denitrification likely generated a lower $\delta^{15} \mathrm{~N}_{\text {sediment }}$ compared to the present-day, since the $\delta^{15} \mathrm{~N}$ of the global $\mathrm{NO}_{3}{ }_{3}^{-}$pool was shifted to a lower value. Additional information on nitrogen cycle processes can be derived from 575 diagnostic biomarkers (Kuypers et al., 2002; Bauersachs et al., 2010).

\section{Nitrogenous, ferruginous or euxinic conditions along anoxic ocean margins in the Phanerozoic?}

In studies on biogeochemical cycling in pre-Cenozoic Earth history, ocean anoxia is typically associated with euxinic or ferruginous conditions in the water column whereas nitrogenous (to weakly sulfidic) conditions, the predominant expression of anoxia in the modern ocean, are often neglected. The

580 definition of euxinic conditions is based on the presence of dissolved $\mathrm{H}_{2} \mathrm{~S}$ in the water column (Meyer and Kump, 2008; Lyons et al., 2009) whereas ferruginous conditions are assigned to anoxic waters that contain dissolved Fe but no hydrogen sulfide (Poulton and Canfield, 2011). Euxinic and ferruginous conditions are differentiated based on sedimentary Fe speciation (Fig. 8). Elevated $\mathrm{Fe}_{\mathrm{HR}} / \mathrm{Fe}_{\mathrm{T}}\left(\mathrm{Fe}_{\mathrm{HR}} / \mathrm{Fe}_{\mathrm{T}}>\right.$ 0.38 ) indicates anoxia while the extent of pyritization determines whether conditions were ferruginous $585\left(\mathrm{Fe}_{\mathrm{py}} / \mathrm{Fe}_{\mathrm{HR}}<0.8\right)$ or euxinic $\left(\mathrm{Fe}_{\mathrm{py}} / \mathrm{Fe}_{\mathrm{HR}}>0.8\right)$ (Poulton and Canfield, 2011).

The concept of an anoxic and ferruginous ocean was originally assigned to the Archean era. Prior to the onset of oxic weathering of sulfide minerals on land the ocean was poor in sulfate. Under these circumstances, $\mathrm{H}_{2} \mathrm{~S}$ produced by near-complete sulfate reduction could be quantitatively titrated by Fe supplied by hydrothermal venting and, subsequently, dissolved Fe could rise to appreciable levels $\left(\mathrm{Fe}^{2+}>\right.$ $590 \mathrm{H}_{2} \mathrm{~S}$ ) (Holland, 1984; Canfield, 1998; Poulton and Canfield, 2011). Greatly enhanced Fe mobility and transport in the ferruginous ocean of the Archean (and Proterozoic) is manifested in the deposition of banded iron formations (Bekker et al., 2010). Sulfate-depleted (sulfate $<50 \mu \mathrm{M}$ ) tropical lakes like Lake Matano provide a meaningful analogue for Fe cycling in a ferruginous ocean during the Precambrian (Crowe et al., 2008). 
More recently, the proxy signature of ferruginous conditions has been reported for a number of Phanerozoic sections where quantitative sulfate consumption is in many cases inconsistent with the sulfur isotope record (März et al., 2008; Dickson et al., 2014; Lenniger et al., 2014; Poulton et al., 2015; Clarkson et al., 2016). In a scenario where dissolved sulfate concentrations are very low (sulfate $<200$ $\mu \mathrm{M})$, the $\delta^{34} \mathrm{~S}$ of sedimentary pyrite is expected to approach the sulfur isotope composition of 600 contemporary seawater (e.g., as constrained from sulfate-containing evaporite samples) (Canfield and Raiswell, 1999; Habicht et al., 2002). Conversely, if pyrite-sulfur is characterized by an isotopic offset from contemporary seawater (i.e., $\delta^{34} \mathrm{~S}_{\text {pyrite }}<\delta^{34} \mathrm{~S}_{\text {seawater }}$ ), sulfate reduction must be incomplete and ferruginous conditions cannot be attributed to quantitative sulfate depletion. In these cases, ferruginous conditions are thought to be a redox state intermediate between nitrogenous and euxinic, where 605 dissolved $\mathrm{Fe}^{2+}$ is the dominant redox species in the water column $\left(\mathrm{Fe}^{2+}>\mathrm{H}_{2} \mathrm{~S}, \mathrm{NO}_{3}{ }^{-} / \mathrm{NO}_{2}{ }^{-}\right)($Poulton and Canfield, 2011).

In the modern ocean such an intermediate stage of ferruginous conditions does not exist in the water column but only in the sediment pore water (Fig 1B). In fact, the highest Fe concentrations observed in the Peruvian OMZ and the Black Sea (tens to hundreds of $n M$ ) coincide with several orders of magnitude 610 higher concentrations of $\mathrm{NO}_{3}{ }^{-} / \mathrm{NO}_{2}{ }^{-}$or $\mathrm{H}_{2} \mathrm{~S}\left(\mathrm{NO}_{3}{ }^{-} / \mathrm{NO}_{2}{ }^{-}\right.$or $\left.\mathrm{H}_{2} \mathrm{~S}>\mathrm{Fe}^{2+}\right)$ (Fig. 1B, $2 \mathrm{~B}$ and 3). Multiple factors can explain the lack of a Fe-dominated intermediate redox state in these systems. In the water column of the Black Sea, solid Fe (oxyhydr)oxide minerals are several orders of magnitude less abundant and have a shorter residence time compared to dissolved sulfate (Lewis and Landing, 1991). Therefore, Fe reduction in sinking particles cannot outpace $\mathrm{H}_{2} \mathrm{~S}$ generation by bacterial sulfate reduction. Instead, a rapid switch

615 from nitrogenous to weakly sulfidic conditions takes place with no Fe-rich and $\mathrm{NO}_{3}{ }^{-} / \mathrm{NO}_{2}{ }^{-}$-depleted and non-sulfidic stage in between. During sulfidic events on the Peruvian margin, $\mathrm{Fe}^{2+}$ and $\mathrm{H}_{2} \mathrm{~S}$ are jointly released from the sediment into the water column upon $\mathrm{NO}_{3}{ }^{-}$and $\mathrm{NO}_{2}{ }^{-}$depletion in the bottom water (Scholz et al., 2016; Sommer et al., 2016). Here, the lack of a ferruginous intermediate stage prior to the onset of weakly sulfidic conditions in the water column is likely related to the high solubility of reduced 620 Fe in weakly sulfidic waters (Rickard, 2006). By contrast, in the pore water of anoxic sediments, ferruginous conditions can readily establish because solid Fe (oxyhydr)oxide minerals are in stationary contact with a relatively small volume of seawater.

According to Poulton and Canfield (2011), ferruginous anoxia dominates over euxinia during times of reduced seawater sulfate concentrations and enhanced reactive Fe supply to the ocean, e.g., due to 625 intensified chemical weathering under conditions of elevated atmospheric $\mathrm{CO}_{2}$ and warmer climate. Under such circumstances, an excess of highly reactive Fe over sulfate is thought to facilitate the onset of 
ferruginous conditions in the water column, despite the presence of leftover sulfate. In this context, it is worth noting that sedimentary $\mathrm{H}_{2} \mathrm{~S}$ release on the Peruvian shelf can take place despite the presence of unsulfidized Fe (oxhydr)oxide minerals in the surface sediment (Scholz et al., 2016). More research on sulfate-lean (few mM of sulfate), tropical brackish water systems could help to better constrain the circumstances under which ferruginous conditions can establish in the water column at the presence of leftover sulfate. However, as demonstrated in Section 3.1. Fe transport in the water column and redistribution of sedimentary reactive $\mathrm{Fe}$ does not necessarily require a water column where $\mathrm{Fe}^{2+}$ dominates over $\mathrm{NO}_{3}{ }^{-} / \mathrm{NO}_{2}{ }^{-}$and $\mathrm{H}_{2} \mathrm{~S}$. Even under the nitrogenous to weakly sulfidic conditions prevailing in modern OMZs dissolved Fe concentrations in the water column are elevated and sediment-derived Fe can be transported, which is demonstrated by significant sedimentary Fe enrichments in the Gulf of California and on the Peruvian margin. In fact, recalculating the $\mathrm{Fe}_{\mathrm{T}} / \mathrm{Al}$ and $\mathrm{Fe}_{\mathrm{HR}} / \mathrm{Fe}_{\mathrm{T}}$ observed in these settings for a lower MAR of terrigenous material (like in the pelagic Black Sea) yields a proxy signature that is indicative of ferruginous conditions (Fig. 8A).

The theoretical effect of enhanced terrigenous Fe supply to continental margin sediments on sedimentary Fe redistribution can be evaluated in Fig. 8B. More intense weathering of silicate minerals and an accumulation of Fe (oxyhydr)oxides, e.g., through expansion of tropical laterite soils, would shift the $\mathrm{Fe}_{\mathrm{T}} / \mathrm{Al}$ and $\mathrm{Fe}_{\mathrm{HR}} / \mathrm{Fe}_{\mathrm{T}}$ of terrigenous particles and thus the relationship between $\mathrm{Fe}_{\mathrm{T}} / \mathrm{Al}$ and $\mathrm{Fe}_{\mathrm{HR}} / \mathrm{Fe}_{\mathrm{T}}$ to higher values. Moreover, more intense weathering of Fe-rich rock types (e.g., more mafic than felsic igneous rocks) (Nockolds, 1954) in the hinterland would yield a higher $\mathrm{Fe}_{\mathrm{T}} / \mathrm{Al}$ and, thus, shift the relationship parallel to the $y$-axis. Both of these trends facilitate the generation of a ferruginous proxy signature at a given MAR and authigenic Fe rain rate (Fig. $8 \mathrm{~B}$ ), regardless of whether $\mathrm{NO}_{3}{ }^{-} / \mathrm{NO}_{2}{ }^{-}, \mathrm{Fe}^{2+}$ or $\mathrm{H}_{2} \mathrm{~S}$ are the dominant redox species in the water column. Based on this reasoning, I propose that the ferruginous proxy signature is generally consistent with nitrogenous to weakly sulfidic conditions like those observed at intermediate depth in the Black Sea (100 - 250 m water depth) (Fig. 2B) and in the water column overlying the Peruvian shelf.

\section{Summary and future directions}

Anoxic OMZs in the modern ocean are characterized by nitrogenous to weakly sulfidic conditions in the water column and ferruginous to sulfidic conditions in the surface sediment. A combination of Feand trace metal-based paleo-proxies can be used to identify this redox structure and the associated biogeochemical processes and feedback mechanisms in sedimentary archives. A generalized model of sedimentary Fe release and trapping was used to demonstrate that the extent of Fe mobilization and transport in modern OMZs can be comparable to that inferred for the euxinic Black Sea and ferruginous 
water columns in Earth history. Based on this finding it is argued that the ferruginous proxy signature is broadly consistent with Fe cycling under OMZ-type redox conditions, especially if enhanced chemical weathering and reactive Fe input to the ocean during past periods of global warming are taken into account.

A specific trend line of $\mathrm{Fe}_{\mathrm{T}} / \mathrm{Al}$ versus $\mathrm{Fe}_{\mathrm{HR}} / \mathrm{Fe}_{\mathrm{T}}$ is proposed as a tool to identify sedimentary Fe release and trapping in the paleo-record. Deviations from this trend line indicate that additional processes, such 665 as changes in terrestrial weathering intensity or Fe transfer from/to the pool of silicate minerals, have to be taken into account in the interpretation of Fe proxy signatures. Sediment geochemical data from paleo-records that plot along the trend line for Fe release and trapping imply that Fe mobility in the surface sediment and bottom water of the paleo-environment was enhanced. Ample Fe supply to the photic zone under these circumstances may have amplified nitrogen fixation and primary production,

670 thus contributing to $\mathrm{OMZ}$ expansion and the development of euxinic conditions along productive continental margins in Earth history (e.g., Grice et al., 2005; Owens et al., 2013).

As a summary of this review article, I propose a proxy-based scheme for the distinction between restricted basin-type and open-marine anoxic settings with non-euxinic or euxinic conditions in the water column (Fig. 9). Non-euxinic conditions can be nitrogenous to weakly sulfidic or ferruginous with or 675 without leftover sulfate. All of these modes of non-euxinic ocean anoxia are compatible with a ferruginous Fe proxy signature and dynamic transitions among them are a conceivable possibility. The sulfur and nitrogen isotopic trends assigned to these modes in Fig. 9 are tentative and meant to inspire future research on how coupled nitrogen, Fe and sulfur cycling along anoxic ocean margins has evolved. Most studies on biogeochemical cycling in pre-Cenozoic Earth history focus on proxies for Fe and sulfur 680 cycling to differentiate between euxinic and ferruginous anoxia. Adding proxies for nitrogen cycling to this routine may provide new insights into how nitrogen cycling processes (denitrification) affected Fe mobility during past periods of ocean anoxia (e.g., Michiels et al., 2017). More work on sedimentary Fe speciation and redistribution in modern OMZs is required to better characterize controlling factors and the extent of Fe release, transport and trapping along productive continental margins. For instance, 685 chemical weathering in tropical river catchments, intense terrigenous input by large streams and an extended shelf width on passive continental margins are factors that are likely to affect the extent of sedimentary Fe redistribution in OMZs.

Many of the biogeochemical processes described in this article have been shown to affect the isotope composition of metals (e.g., vanadium, chromium, iron, molybdenum, thallium, uranium) (Teng et al., 2017). However, with the exception of Fe and Mo (e.g., Poulson et al., 2006; Poulson-Brucker et al., 
2009; Severmann et al., 2006, 2010; Scholz et al., 2014a, b, 2017), none of these promising isotope geochemical tools has been studied in a systematic fashion in OMZs (i.e., across the entire bottom water redox-gradient, ideally including not only sediments but also pore waters and suspended particulate matter). Comparing sedimentary trace metal ratios and metal isotope values with trace metal quota and isotope compositions of different biological communities could help to identify specific metabolisms that are associated with nitrogenous or euxinic conditions at open-marine continental margins in Earth history. More research on the distribution, isotope composition and/or speciation (dissolved, particles, sediment) of metals that accumulate under anoxic but non-sulfidic conditions (e.g., rhenium, chromium, vanadium) can provide valuable insights into the specific sedimentary fingerprint of redox gradients at the boundaries between nitrogenous and oxic or euxinic water masses. Combining such novel tools with well-established geochemical proxies in both modern and ancient anoxic settings will help to better constrain the role and abundance of OMZ-type biogeochemical cycling throughout Earth history.

\section{Acknowledgements}

I would like to thank Klaus Wallmann and Jim McManus for providing comments on an earlier version of this manuscript as well as for arousing my interest in the role of sediments in ocean biogeochemical dynamics. Furthermore, I would like to thank Andy Dale, Don Canfield, Chris Siebert, Simon Poulton, Silke Severmann, Andreas Kappler, Emma Hammarlund and Jim Moffett for helpful discussions and scientific exchange over the past years. This work was supported by the German Research Foundation (DFG) through my Emmy Noether Research Group (ICONOX - Iron Cycling in Marine Sediments and the

710 Nutrient and Oxygen Balance of the Ocean) and Collaborative Research Centre 754 (ClimateBiogeochemistry Interactions in the Tropical Ocean). Insightful comments from two reviewers and editorial handling by André Strasser helped to improve the manuscript and are gratefully acknowledged.

\section{References}

Ader, M., Thomazo, C., Sansjofre, P., Busigny, V., Papineau, D., Laffont, R., Cartigny, P. and Halverson, G.P. (2016) Interpretation of the nitrogen isotopic composition of Precambrian sedimentary rocks: Assumptions and perspectives. Chemical Geology 429, 93-110.

Algeo, T.J. and Ingall, E. (2007) Sedimentary Corg:P ratios, paleocean ventilation, and Phanerozoic atmospheric $\mathrm{pO}_{2}$. Palaeogeography, Palaeoclimatology, Palaeoecology 256, 130-155.

Algeo, T.J. and Lyons, T.W. (2006) Mo-total organic carbon covariation in modern anoxic marine environments: Implications for analysis of paleoredox and paleohydrographic conditions. Paleoceanography 21, PA1016. 
Algeo, T.J., Meyers, P.A., Robinson, R.S., Rowe, H. and Jiang, G.Q. (2014) Icehouse-greenhouse variations in marine denitrification. Biogeosciences 11, 1273-1295.

Altabet, M.A., Francois, R., Murray, D.W. and Prell, W.L. (1995) Climate-related variations in denitrification in the Arabian Sea from sediment 15N/14N ratios. Nature 373, 506.

Barnes, C.E. and Cochran, J.K. (1990) Uranium removal in oceanic sediments and the oceanic U balance. Earth and Planetary Science Letters 97, 94-101.

Bauersachs, T., Speelman, E.N., Hopmans, E.C., Reichart, G.-J., Schouten, S. and Damsté, J.S.S. (2010) Fossilized glycolipids reveal past oceanic N2 fixation by heterocystous cyanobacteria. Proceedings of the National Academy of Sciences 107, 19190-19194.

Bekker, A., Slack, J.F., Planavsky, N., Krapez, B., Hofmann, A., Konhauser, K.O. and Rouxel, O.J. (2010) Iron formation: The sedimentary product of a complex interplay among mantle, tectonic, oceanic, and biospheric processes. Economic Geology 105, 467-508.

Benson, B.B. and Krause Jr., D. (1980) The concentration and isotope fractionation of gases dissolved in freshwater in equilibrium with the atmosphere: 1. Oxygen. Limnology and Oceanography 25, 662671.

Bohlen, L., Dale, A.W., Sommer, S., Mosch, T., Hensen, C., Noffke, A., Scholz, F. and Wallmann, K. (2011) Benthic nitrogen cycling traversing the Peruvian oxygen minimum zone. Geochimica et Cosmochimica Acta 75, 6094-6111.

740 Böning, P., Brumsack, H.J., Böttcher, M.E., Schnetger, B., Kriete, C., Kallmeyer, J. and Borchers, S.L. (2004) Geochemistry of Peruvian near-surface sediments. Geochimica Et Cosmochimica Acta 68, 4429-4451.

Böning, P., Cuypers, S., Grunwald, M., Schnetger, B. and Brumsack, H.J. (2005) Geochemical characteristics of Chilean upwelling sediments at $\sim 36^{\circ} \mathrm{S}$. Marine Geology 220, 1-21.

Borchers, S.L., Schnetger, B., Boning, P. and Brumsack, H.J. (2005) Geochemical signatures of the Namibian diatom belt: Perennial upwelling and intermittent anoxia. Geochemistry Geophysics Geosystems 6, Q06006, doi:10.1029/2004GC000886.

Boyd, P.W. and Ellwood, M.J. (2010) The biogeochemical cycle of iron in the ocean. Nature Geoscience 3, 675-682.

Boyle, R.A., Clark, J.R., Poulton, S.W., Shields-Zhou, G., Canfield, D.E. and Lenton, T.M. (2013) Nitrogen 750 cycle feedbacks as a control on euxinia in the mid-Proterozoic ocean. Nature Communications 4, 1533. 
Brandt, P., Bange, H.W., Banyte, D., Dengler, M., Didwischus, S.H., Fischer, T., Greatbatch, R.J., Hahn, J., Kanzow, T., Karstensen, J., Körtzinger, A., Krahmann, G., Schmidtko, S., Stramma, L., Tanhua, T. and Visbeck, M. (2015) On the role of circulation and mixing in the ventilation of oxygen minimum zones with a focus on the eastern tropical North Atlantic. Biogeosciences 12, 489-512.

Brüchert, V., Jørgensen, B.B., Neumann, K., Riechmann, D., Schlösser, M. and Schulz, H. (2003) Regulation of bacterial sulfate reduction and hydrogen sulfide fluxes in the central namibian coastal upwelling zone. Geochimica et Cosmochimica Acta 67, 4505-4518.

Bruland, K.W., Rue, E.L., Smith, G.J. and DiTullio, G.R. (2005) Iron, macronutrients and diatom blooms in 760 the Peru upwelling regime: brown and blue waters of Peru. Marine Chemistry 93, 81-103.

Brumsack, H.-J. (1986) The inorganic geochemistry of Cretaceous black shales (DSDP Leg 41) in comparison to modern upwelling sediments from the Gulf of California. Geological Society, London, Special Publications 21, 447-462.

Brumsack, H.-J. (1989) Geochemistry of recent TOC-rich sediments from the Gulf of California and the Black Sea. International Journal of Earth Sciences 78, 851-882.

Brumsack, H.-J. (2006) The trace metal content of recent organic carbon-rich sediments: Implications for Cretaceous black shale formation. Palaeogeography, Palaeoclimatology, Palaeoecology 232, 344-361.

Burdige, D.J. (2007) Preservation of organic matter in marine sediments: Controls, mechanisms, and an imbalance in sediment organic carbon budgets? Chemical Reviews 107, 467-485.

770 Calvert, S.E. (1966) Accumulation of diatomaceous silica in the sediments of the Gulf of California. Geological Society of America Bulletin 77, 569-596.

Calvert, S.E., Karlin, R.E., Toolin, L.J., Donahue, D.J., Southon, J.R. and Vogel, J.S. (1991) Low organic carbon accumulation rates in Black Sea sediments. Nature 350, 692.

Campbell, A.C. and Gieskes, J.M. (1984) Water column anomalies associated with hydrothermal activity 775 in the Guaymas Basin, Gulf of California. Earth and Planetary Science Letters 68, 57-72.

Canfield, D.E. (1989) Reactive iron in marine sediments. Geochimica et Cosmochimica Acta 53, 619-632.

Canfield, D.E. (1998) A new model for Proterozoic ocean chemistry. Nature 396, 450-453.

Canfield, D.E. (2006) Models of oxic respiration, denitrification and sulfate reduction in zones of coastal upwelling. Geochimica et Cosmochimica Acta 70, 5753-5765.

780 Canfield, D.E. and Raiswell, R. (1999) The evolution of the sulfur cycle. American Journal of Science 299, 697-723. 
Canfield, D.E., Raiswell, R., Westrich, J.T., Reaves, C.M. and Berner, R.A. (1986) The use of chromium reduction in the analysis of reduced inorganic sulfur in sediments and shales. Chemical Geology 54, 149-155.

Canfield, D.E., Raiswell, R. and Bottrell, S.H. (1992) The reactivity of sedimentary iron minerals toward sulfide. American Journal of Science 292, 659-683.

Canfield, D.E. and Thamdrup, B. (2009) Towards a consistent classification scheme for geochemical environments, or, why we wish the term 'suboxic' would go away. Geobiology 7, 385-392.

Chan, K.M. and Riley, J.P. (1966) The determination of molybdenum in natural waters, silicates and biological materials. Analytica Chimica Acta 36, 220-229.

Chan, K.M. and Riley, J.P. (1966) The determination of vanadium in sea and natural waters,biological materials and silicate sediments and rocks. Analytica Chimica Acta 34, 337-345.

Clarkson, M.O., Wood, R.A., Poulton, S.W., Richoz, S., Newton, R.J., Kasemann, S.A., Bowyer, F. and Krystyn, L. (2016) Dynamic anoxic ferruginous conditions during the end-Permian mass extinction and recovery. Nature Communications 7.

Crowe, S.A., Jones, C., Katsev, S., Magen, C., O'Neill, A.H., Sturm, A., Canfield, D.E., Haffner, G.D., Mucci, A., Sundby, B. and Fowle, D.A. (2008) Photoferrotrophs thrive in an Archean Ocean analogue. Proceedings of the National Academy of Sciences 105, 15938-15943.

Dahl, T.W., Ruhl, M., Hammarlund, E.U., Canfield, D.E., Rosing, M.T. and Bjerrum, C.J. (2013) Tracing 800 euxinia by molybdenum concentrations in sediments using handheld X-ray fluorescence spectroscopy (HHXRF). Chemical Geology 360â€“361, 241-251.

Dale, A.W., Nickelsen, L., Scholz, F., Hensen, C., Oschlies, A. and Wallmann, K.C.G. (2015) A revised global estimate of dissolved iron fluxes from marine sediments. Global Biogeochemical Cycles $10.1002 / 2014 G B 005017$.

805 Dale, A.W., Graco, M. and Wallmann, K. (2017) Strong and dynamic benthic-pelagic coupling and feedbacks in a coastal upwelling system (Peruvian shelf). Frontiers in Marine Science 4, doi: 10.3389/fmars.2017.00029.

Dalsgaard, T., Canfield, D.E., Petersen, J., Thamdrup, B. and Acuna-Gonzalez, J. (2003) N2 production by the anammox reaction in the anoxic water column of Golfo Dulce, Costa Rica. Nature 422, 606-608.

810 Dellwig, O., Leipe, T., März, C., Glockzin, M., Pollehne, F., Schnetger, B., Yakushev, E.V., Böttcher, M.E. and Brumsack, H.-J. (2010) A new particulate Mn-Fe-P-shuttle at the redoxcline of anoxic basins. Geochimica et Cosmochimica Acta 74, 7100-7115. 
Diaz, R.J. (2001) Overview of hypoxia around the world. Journal of Environmental Quality 30, 275-281.

Diaz, R.J. and Rosenberg, R. (2008) Spreading dead zones and consequences for marine ecosystems. Science 321, 926-929.

Dickson, A.J., Rees-Owen, R.L., März, C., Coe, A.L., Cohen, A.S., Pancost, R.D., Taylor, K. and Shcherbinina, E. (2014) The spread of marine anoxia on the northern Tethys margin during the Paleocene-Eocene Thermal Maximum. Paleoceanography 29, 2014PA002629.

Elrod, V.A., Berelson, W.M., Coale, K.H. and Johnson, K.S. (2004) The flux of iron from continental shelf sediments: A missing source for global budgets. Geophys. Res. Lett. 31.

Emerson, S.R. and Huested, S.S. (1991) Ocean anoxia and the concentrations of molybdenum and vanadium in seawater. Marine Chemistry 34, 177-196.

Erickson, B.E. and Helz, G.R. (2000) Molybdenum(VI) speciation in sulfidic waters:: Stability and lability of thiomolybdates. Geochimica et Cosmochimica Acta 64, 1149-1158.

825 Falkowski, P.G. (1997) Evolution of the nitrogen cycle and its influence on the biological sequestration of CO2 in the ocean. Nature 387, 272-275.

Ferdelman, T.G., Lee, C., Pantoja, S., Harder, J., Bebout, B.M. and Fossing, H. (1997) Sulfate reduction and methanogenesis in a Thioploca-dominated sediment off the coast of Chile. Geochimica et Cosmochimica Acta 61, 3065-3079.

Fossing, H., Gallardo, V.A., Jørgensen, B.B., Hüttel, M., Nielsen, L.P., Schulz, H., Canfield, D.E., Forster, S., Glud, R.N., Gundersen, J.K., Küver, J., Ramsing, N.B., Teske, A., Thamdrup, B. and Ulloa, O. (1995) Concentration and transport of nitrate by the mat-forming sulphur bacterium Thioploca. Nature 374, 713.

Friederich, G.E., Codispoti, L.A. and Sakamoto, C.M. (1990) Bottle and pumpcast data from the 1988 Black Sea expedition, Monterey Bay Aquarium Research Institute Technical Report No. 90-3.

Galbraith, E.D., Kienast, M., Pedersen, T.F. and Calvert, S.E. (2004) Glacial-interglacial modulation of the marine nitrogen cycle by high-latitude 02 supply to the global thermocline. Paleoceanography 19, PA4007.

Ganeshram, R.S., Pedersen, T.F., Calvert, S.E., McNeill, G.W. and Fontugne, M.R. (2000) Glacialinterglacial variability in denitrification in the world's oceans: Causes and consequences. Paleoceanography 15, 361-376. 
Glenn, C.R. and Arthur, M.A. (1988) Petrology and major element geochemistry of Peru margin phosphorites and associated diagenetic minerals: Authigenesis in modern organic-rich sediments. Marine Geology 80, 231-267.

Grégoire, M. and Beckers, J.M. (2004) Modeling the nitrogen fluxes in the Black Sea using a 3D coupled hydrodynamical-biogeochemical model: Transport versus biogeochemical processes, exchanges across the shelf break and comparison of the shelf and deep sea ecodynamics. Biogeosciences 1, 3361.

Grice, K., Cao, C., Love, G.D., Böttcher, M.E., Twitchett, R.J., Grosjean, E., Summons, R.E., Turgeon, S.C., 850 Dunning, W. and Jin, Y. (2005) Photic zone euxinia during the Permian-Triassic superanoxic event. Science 307, 706-709.

Gruber, N. (2008) The marine nitrogen cycle: Overview and challenges, in: Capone, D.G., Bronk, D.A., Mulholland, M.R., Carpenter, E.J. (Eds.), Nitrogen in the marine environment. Academic Press, pp. 150.

Gruber, N. and Sarmiento, J.L. (1997) Global patterns of marine nitrogen fixation and denitrification. Global Biogeochemical Cycles 11, 235-266.

Guilbaud, R., Slater, B.J., Poulton, S.W., Harvey, T.H.P., Brocks, J.J., Nettersheim, B.J. and Butterfield, N.J. (2018) Oxygen minimum zones in the early Cambrian ocean. Geochemical Perspectives Letters 6, 3338.

Habicht, K.S., Gade, M., Thamdrup, B., Berg, P. and Canfield, D.E. (2002) Calibration of sulfate levels in the Archean ocean. Science 298, 2372-2374.

Hamersley, M.R., Lavik, G., Woebken, D., Rattray, J.E., Lam, P., Hopmans, E.C., Damste, J.S.S., Kruger, S., Graco, M., Gutierrez, D. and Kuypers, M.M.M. (2007) Anaerobic ammonium oxidation in the Peruvian oxygen minimum zone. Limnology and Oceanography 52, 923-933.

Hammarlund, E.U., Gaines, R.R., Prokopenko, M.G., Qi, C., Hou, X.-G. and Canfield, D.E. (2017) Early Cambrian oxygen minimum zone-like conditions at Chengjiang. Earth and Planetary Science Letters $475,160-168$.

Harder, H. (1980) Syntheses of glauconite at surface temperatures. Clays and Clay Minerals 28, 217-222.

Hawco, N.J., Ohnemus, D.C., Resing, J.A., Twining, B.S. and Saito, M.A. (2016) A dissolved cobalt plume in the oxygen minimum zone of the eastern tropical South Pacific. Biogeosciences 13, 5697-5717. 
Heller, M.I., Lam, P.J., Moffett, J.W., Till, C.P., Lee, J.-M., Toner, B.M. and Marcus, M.A. (2017) Accumulation of $\mathrm{Fe}$ oxyhydroxides in the Peruvian oxygen deficient zone implies non-oxygen dependent Fe oxidation. Geochimica et Cosmochimica Acta 211, 174-193.

Helz, G.R., Miller, C.V., Charnock, J.M., Mosselmans, J.F.W., Pattrick, R.A.D., Garner, C.D. and Vaughan, 875 D.J. (1996) Mechanism of molybdenum removal from the sea and its concentration in black shales: EXAFS evidence. Geochimica et Cosmochimica Acta 60, 3631-3642.

Higgins, M.B., Robinson, R.S., Husson, J.M., Carter, S.J. and Pearson, A. (2012) Dominant eukaryotic export production during ocean anoxic events reflects the importance of recycled $\mathrm{NH} 4+$. Proceedings of the National Academy of Sciences 109, 2269-2274.

880 Ho, P., Lee, J.-M., Heller, M.I., Lam, P.J. and Shiller, A.M. (2018) The distribution of dissolved and particulate Mo and V along the U.S. GEOTRACES East Pacific Zonal Transect (GP16): The roles of oxides and biogenic particles in their distributions in the oxygen deficient zone and the hydrothermal plume. Marine Chemistry 201, 242-255.

Holland, H. D. (1984). The chemical evolution of the atmosphere and oceans. Princeton University Press, Princeton.

Howarth, R., Chan, F., Conley, D.J., Garnier, J., Doney, S.C., Marino, R. and Billen, G. (2011) Coupled biogeochemical cycles: Eutrophication and hypoxia in temperate estuaries and coastal marine ecosystems. Frontiers in Ecology and the Environment 9, 18-26.

Hutchins, D.A. and Bruland, K.W. (1998) Iron-limited diatom growth and Si:N uptake ratios in a coastal upwelling regime. Nature 393, 561-564.

Ingall, E. and Jahnke, R. (1994) Evidence for enhanced phosphorus regeneration from marine sediments overlain by oxygen depleted waters. Geochimica et Cosmochimica Acta 58, 2571-2575.

Ingall, E. and Jahnke, R. (1997) Influence of water-column anoxia on the elemental fractionation of carbon and phosphorus during sediment diagenesis. Marine Geology 139, 219-229.

Ingall, E.D. and Van Cappellen, P. (1990) Relation between sedimentation rate and burial of organic phosphorus and organic carbon in marine sediments. Geochimica et Cosmochimica Acta 54, 373-386.

Johnson, K.S., Berelson, W.M., Coale, K.H., Coley, T.L., Elrod, V.A., Fairey, W.R., Iams, H.D., Kilgore, T.E. and Nowicki, J.L. (1992) Manganese Flux from Continental-Margin Sediments in a Transect through the Oxygen Minimum. Science 257, 1242-1245.

900 Johnson, K.S., Chavez, F.P. and Friederich, G.E. (1999) Continental-shelf sediment as a primary source of iron for coastal phytoplankton. Nature 398, 697-700. 
Johnson, K.S., Coale, K.H., Berelson, W.M. and Michael Gordon, R. (1996) On the formation of the manganese maximum in the oxygen minimum. Geochimica et Cosmochimica Acta 60, 1291-1299.

Karstensen, J., Stramma, L. and Visbeck, M. (2008) Oxygen minimum zones in the eastern tropical Atlantic and Pacific oceans. Progress in Oceanography 77, 331-350.

Keeling, R.F., Körtzinger, A. and Gruber, N. (2011) Ocean deoxygenation in a warming world. Annual Review of Marine Science 2, 199-229.

Klinkhammer, G.P. and Bender, M.L. (1980) The distribution of manganese in the Pacific Ocean. Earth and Planetary Science Letters 46, 361-384.

910 Klinkhammer, G.P. and Palmer, M.R. (1991) Uranium in the oceans - Where it goes and why. Geochimica et Cosmochimica Acta 55, 1799-1806.

Klinkhammer, G.P., Mix, A.C. and Haley, B.A. (2009) Increased dissolved terrestrial input to the coastal ocean during the last deglaciation. Geochemistry Geophysics Geosystems 10, Q03009, doi:03010.01029/02008GC002219.

915 Klueglein, N. and Kappler, A. (2013) Abiotic oxidation of Fe(II) by reactive nitrogen species in cultures of the nitrate-reducing Fe(II) oxidizer Acidovorax sp. BoFeN1 - questioning the existence of enzymatic Fe(II) oxidation. Geobiology 11, 180-190.

Kondo, Y. and Moffett, J.W. (2015) Iron redox cycling and subsurface offshore transport in the eastern tropical South Pacific oxygen minimum zone. Marine Chemistry 168, 95-103.

920 Koschinsky, A. and Halbach, P. (1995) Sequential leaching of marine ferromanganese precipitates: Genetic implications. Geochimica et Cosmochimica Acta 59, 5113-5132.

Kuypers, M.M.M., Lavik, G., Woebken, D., Schmid, M., Fuchs, B.M., Amann, R., JÃ ,rgensen, B.B. and Jetten, M.S.M. (2005) Massive nitrogen loss from the Benguela upwelling system through anaerobic ammonium oxidation. Proceedings of the National Academy of Sciences of the United States of $925 \quad$ America 102, 6478-6483.

Kuypers, M.M.M., Pancost, R.D., Nijenhuis, I.A. and Sinninghe Damsté, J.S.C. (2002) Enhanced productivity led to increased organic carbon burial in the euxinic North Atlantic basin during the late Cenomanian oceanic anoxic event. Paleoceanography 17, 3-1-3-13.

Kuypers, M.M.M., Sliekers, A.O., Lavik, G., Schmid, M., Jorgensen, B.B., Kuenen, J.G., Sinninghe Damsté, 930 J.S., Strous, M. and Jetten, M.S.M. (2003) Anaerobic ammonium oxidation by anammox bacteria in the Black Sea. Nature 422, 608. 
Lam, P. and Kuypers, M.M.M. (2011) Microbial nitrogen cycling processes in oxygen minimum zones. Annual Review of Marine Science 3, 317-345.

Landing, W.M. and Bruland, K.W. (1987) The contrasting biogeochemistry of iron and manganese in the Pacific Ocean. Geochimica et Cosmochimica Acta 51, 29-43.

Landolfi, A., Dietze, H., Koeve, W. and Oschlies, A. (2013) Overlooked runaway feedback in the marine nitrogen cycle: The vicious cycle. Biogeosciences 10, 1351-1363.

Lenniger, M., Nøhr-Hansen, H., Hills, L.V. and Bjerrum, C.J. (2014) Arctic black shale formation during Cretaceous Oceanic Anoxic Event 2. Geology 42, 799-802.

940 Lewis, B.L. and Landing, W.M. (1991) The biogeochemistry of manganese and iron in the Black Sea. Deep Sea Research Part A. Oceanographic Research Papers 38, Supplement 2, S773-S803.

Lewis, B.L. and Luther III, G.W. (2000) Processes controlling the distribution and cycling of manganese in the oxygen minimum zone of the Arabian Sea. Deep Sea Research 47, 1541-1561.

Loescher, C.R., Groskopf, T., Desai, F.D., Gill, D., Schunck, H., Croot, P.L., Schlosser, C., Neulinger, S.C., 945 Pinnow, N., Lavik, G., Kuypers, M.M.M., LaRoche, J. and Schmitz, R.A. (2014) Facets of diazotrophy in the oxygen minimum zone waters off Peru. ISME J.

Lohan, M.C. and Bruland, K.W. (2008) Elevated Fe(II) and dissolved Fe in hypoxic shelf waters off Oregon and Washington: An enhanced source of iron to coastal upwelling regimes. Environ. Sci. Technol. 42, 6462-6468.

950 Lovley, D.R., Phillips, E.J.P., Gorby, Y.A. and Landa, E.R. (1991) Microbial reduction of uranium. Nature $350,413-416$.

Lyons, T.W., Anbar, A.D., Severmann, S., Scott, C. and Gill, B.C. (2009) Tracking euxinia in the ancient ocean: A multiproxy perspective and Proterozoic case study. Annu. Rev. Earth Planet. Sci. 37, 507534.

955 Lyons, T.W. and Severmann, S. (2006) A critical look at iron paleoredox proxies: New insights from modern euxinic marine basins. Geochimica et Cosmochimica Acta 70, 5698-5722.

März, C., Poulton, S.W., Beckmann, B., Kuster, K., Wagner, T. and Kasten, S. (2008) Redox sensitivity of P cycling during marine black shale formation: Dynamics of sulfidic and anoxic, non-sulfidic bottom waters. Geochimica et Cosmochimica Acta 72, 3703-3717.

960 Matear, R.J. and Hirst, A.C.C. (2003) Long-term changes in dissolved oxygen concentrations in the ocean caused by protracted global warming. Global Biogeochemical Cycles 17, n/a-n/a. 
McLennan S. M. (2001) Relationships between the trace element composition of sedimentary rocks and upper continental crust. Geochemistry Geophysics Geosystems 2, paper number 2000GC000109.

McManus, J., Berelson, W.M., Coale, K.H., Johnson, K.S. and Kilgore, T.E. (1997) Phosphorus regeneration in continental margin sediments. Geochimica et Cosmochimica Acta 61, 2891-2907.

McManus, J., Berelson, W.M., Klinkhammer, G.P., Hammond, D.E. and Holm, C. (2005) Authigenic uranium: relationship to oxygen penetration depth and organic carbon rain. Geochimica Et Cosmochimica Acta 69, 95-108.

Meyer, K.M. and Kump, L.R. (2008) Oceanic euxinia in Earth history: Causes and consequences. Annu. Rev. Earth Planet. Sci. 36, 251-288.

Michiels, C.C., Darchambeau, F., Roland, F.A.E., Morana, C., Lliros, M., Garcia-Armisen, T., Thamdrup, B., Borges, A.V., Canfield, D.E., Servais, P., Descy, J.-P. and Crowe, S.A. (2017) Iron-dependent nitrogen cycling in a ferruginous lake and the nutrient status of Proterozoic oceans. Nature Geoscience 10, 217-221.

975 Moore, J.K. and Doney, S.C. (2007) Iron availability limits the ocean nitrogen inventory stabilizing feedbacks between marine denitrification and nitrogen fixation. Global Biogeochemical Cycles 21, GB2001, doi:2010.1029/2006GB002762.

Morford, J.L., Emerson, S.R., Breckel, E.J. and Kim, S.H. (2005) Diagenesis of oxyanions (V, U, Re, and Mo) in pore waters and sediments from a continental margin. Geochimica Et Cosmochimica Acta 69, 50215032.

Mort, H.P., Adatte, T., Keller, G., Bartels, D., Föllmi, K.B., Steinmann, P., Berner, Z. and Chellai, E.H. (2008) Organic carbon deposition and phosphorus accumulation during Oceanic Anoxic Event 2 in Tarfaya, Morocco. Cretaceous Research 29, 1008-1023.

Mosch, T., Sommer, S., Dengler, M., Noffke, A., Bohlen, L., Pfannkuche, O., Liebetrau, V. and Wallmann, K. (2012) Factors influencing the distribution of epibenthic megafauna across the Peruvian oxygen minimum zone. Deep Sea Research Part I: Oceanographic Research Papers 68, 123-135.

Mullins, H.T., Thompson, J.B., McDougall, K. and Vercoutere, T.L. (1985) Oxygen-minimum zone edge effects: Evidence from the central California coastal upwelling system. Geology 13, 491-494.

Murray, J.W., Top, Z. and Özsoy, E. (1991) Hydrographic properties and ventilation of the Black Sea. Deep Sea Research Part A. Oceanographic Research Papers 38, S663-S689.

Nameroff, T.J., Balistrieri, L.S. and Murray, J.W. (2002) Suboxic trace metal geochemistry in the Eastern Tropical North Pacific. Geochimica et Cosmochimica Acta 66, 1139-1158. 
Nockolds, S.R. (1954) Average chemical composition of some igneous rocks. Geological Society of America Bulletin 65, 1007-1032.

Noffke, A., Hensen, C., Sommer, S., Scholz, F., Bohlen, L., Mosch, T., Graco, M. and Wallmann, K. (2012) Benthic iron and phosphorus fluxes across the Peruvian oxygen minimum zone. Limnol. Oceanogr. 57, 851-867.

Ohnemus, D.C., Rauschenberg, S., Cutter, G.A., Fitzsimmons, J.N., Sherrell, R.M. and Twining, B.S. (2017) Elevated trace metal content of prokaryotic communities associated with marine oxygen deficient 1000 zones. Limnology and Oceanography 62, 3-25.

Owens, J.D., Gill, B.C., Jenkyns, H.C., Bates, S.M., Severmann, S., Kuypers, M.M.M., Woodfine, R.G. and Lyons, T.W. (2013) Sulfur isotopes track the global extent and dynamics of euxinia during Cretaceous Oceanic Anoxic Event 2. Proceedings of the National Academy of Sciences 110, 18407-18412.

Özsoy, E. and Ünlüata, U. (1997) Oceanography of the Black Sea: A review of some recent results. Earth1005 Science Reviews 42, 231-272.

Paulmier, A. and Ruiz-Pino, D. (2009) Oxygen minimum zones (OMZs) in the modern ocean. Progress in Oceanography 80, 113-128.

Pennington, J.T., Mahoney, K.L., Kuwahara, V.S., Kolber, D.D., Calienes, R. and Chavez, F.P. (2006) Primary production in the eastern tropical Pacific: A review. Progress In Oceanography 69, 285-317.

1010 Picardal, F. (2012) Abiotic and microbial interactions during anaerobic transformations of Fe(II) and NOx. Frontiers in Microbiology 3, doi: 10.3389/fmicb.2012.00112.

Planavsky, N.J., Cole, D.B., Reinhard, C.T., Diamond, C., Love, G.D., Luo, G., Zhang, S., Konhauser, K.O. and Lyons, T.W. (2016) No evidence for high atmospheric oxygen levels 1,400 million years ago. Proceedings of the National Academy of Sciences 113, E2550-E2551.

1015 Poulson Brucker, R.L., McManus, J., Severmann, S. and Berelson, W.M. (2009) Molybdenum behavior during early diagenesis: Insights from Mo isotopes. Geochemistry Geophysics Geosystems 10.

Poulson, R.L., Siebert, C., McManus, J. and Berelson, W.M. (2006) Authigenic molybdenum isotope signatures in marine sediments. Geology 34, 617-620.

Poulton, S.W. and Canfield, D.E. (2005) Development of a sequential extraction procedure for iron: 1020 implications for iron partitioning in continentally derived particulates. Chemical Geology 214, 209221.

Poulton, S.W. and Canfield, D.E. (2011) Ferruginous conditions: A dominant feature of the ocean through Earth's history. ELEMENTS 7, 107-112. 
Poulton, S.W. and Raiswell, R. (2002) The low-temperature geochemical cycle of iron: From continental 1025 fluxes to marine sediment deposition. American Journal of Science 302, 774-805.

Poulton, S.W., Fralick, P.W. and Canfield, D.E. (2010) Spatial variability in oceanic redox structure 1.8 billion years ago. Nature Geoscience 3, 486-490.

Poulton, S.W., Henkel, S., März, C., Urquhart, H., Flögel, S., Kasten, S., Sinninghe Damsté, J.S. and Wagner, T. (2015) A continental-weathering control on orbitally driven redox-nutrient cycling during 1030 Cretaceous Oceanic Anoxic Event 2. Geology 43, 963-966.

Rabalais, N.N., Diaz, R.J., Levin, L.A., Turner, R.E., Gilbert, D. and Zhang, J. (2010) Dynamics and distribution of natural and human-caused hypoxia. Biogeosciences 7, 585-619.

Raiswell, R. and Canfield, D.E. (1996) Rates of reaction between silicate iron and dissolved sulfide in Peru margin sediments. Geochimica et Cosmochimica Acta 60, 2777-2787.

Raiswell, R. and Canfield, D.E. (1998) Sources of iron for pyrite formation in marine sediments. American Journal of Science 298, 219-245.

Raiswell, R. and Anderson, T.F. (2005) Reactive iron enrichment in sediments deposited beneath euxinic bottom waters: constraints on supply by shelf recycling. Geological Society, London, Special Publications 248, 179-194.

1040 Raiswell, R., Buckley, F., Berner, R.A. and Anderson, T.F. (1988) Degree of pyritization of iron as a paleoenvironmental indicator of bottom-water oxygenation. Journal of Sedimentary Research 58, 812-819.

Raiswell, R. and Canfield, D.E. (2012) The iron biogeochemical cycle past and present. Geochemical Perspectives 1, 1-220.

1045 Redfield, A.C., Ketchum, B.H. and Richards, F.A. (1963) The influence of organisms on the composition of sea-water, in: Hill, M.N. (Ed.), The Sea. Wiley-Interscience, New York, pp. 26-77.

Reimers, C.E. and Suess, E. (1983) Spatial and temporal patterns of organic matter accumulation on the Peru continental margin, in: Suess, E., Thiede, J. (Eds.), Coastal upwelling: Part B. Sedimentary record of ancient coastal upwelling. Plenum Press, New York, pp. 311-346.

1050 Rickard, D. (2006) The solubility of FeS. Geochimica et Cosmochimica Acta 70, 5779-5789.

Schenau, S.J. and De Lange, G.J. (2001) Phosphorus regeneration vs. burial in sediments of the Arabian Sea. Marine Chemistry 75, 201-217.

Schmidtko, S., Stramma, L. and Visbeck, M. (2017) Decline in global oceanic oxygen content during the past five decades. Nature 542, 335-339. 
Scholz, F., Hensen, C., Noffke, A., Rohde, A., Liebetrau, V. and Wallmann, K. (2011) Early diagenesis of redox-sensitive trace metals in the Peru upwelling area: response to ENSO-related oxygen fluctuations in the water column. Geochimica et Cosmochimica Acta 75, 7257-7276.

Scholz, F., McManus, J. and Sommer, S. (2013) The manganese and iron shuttle in a modern euxinic basin and implications for molybdenum cycling at euxinic ocean margins. Chemical Geology 355, 56-68.

Scholz, F., McManus, J., Mix, A.C., Hensen, C. and Schneider, R.R. (2014a) The impact of ocean deoxygenation on iron release from continental margin sediments. Nature Geoscience 7, 433-437.

Scholz, F., Severmann, S., McManus, J. and Hensen, C. (2014b) Beyond the Black Sea paradigm: The sedimentary fingerprint of an open-marine iron shuttle. Geochimica et Cosmochimica Acta 127, 368380.

1065 Scholz, F., Severmann, S., McManus, J., Noffke, A., Lomnitz, U. and Hensen, C. (2014c) On the isotope composition of reactive iron in marine sediments: Redox shuttle versus early diagenesis. Chemical Geology 389, 48-59.

Scholz, F., Löscher, C.R., Fiskal, A., Sommer, S., Hensen, C., Lomnitz, U., Wuttig, K., Göttlicher, J., Kossel, E., Steininger, R. and Canfield, D.E. (2016) Nitrate-dependent iron oxidation limits iron transport in anoxic ocean regions. Earth and Planetary Science Letters 454, 272-281.

Scholz, F., Siebert, C., Dale, A.W. and Frank, M. (2017) Intense molybdenum accumulation in sediments underneath a nitrogenous water column and implications for the reconstruction of paleo-redox conditions based on molybdenum isotopes. Geochimica et Cosmochimica Acta 213, 400-417.

Schulz, H.N., Brinkhoff, T., Ferdelman, T.G., Hernandez Mariné, M., Teske, A. and Jørgensen, B.B. (1999) Dense populations of a giant sulfur bacterium in Namibian shelf sediments. Science 284, 493-495.

Schunck, H., Lavik, G., Desai, D.K., Grosskopf, T., Kalvelage, T., Loescher, C.R., Paulmier, A., Contreras, S., Siegel, H., Holtappels, M., Rosenstiel, P., Schilhabel, M.B., Graco, M., Schmitz, R.A., Kuypers, M.M.M. and LaRoche, J. (2013) Giant hydrogen sulfide plume in the oxygen minimum zone off Peru supports chemolithoautotrophy. Plos One 8.

1080 Scott, C. and Lyons, T.W. (2012) Contrasting molybdenum cycling and isotopic properties in euxinic versus non-euxinic sediments and sedimentary rocks: Refining the paleoproxies. Chemical Geology $324-325,19-27$.

Severmann, S., Johnson, C.M., Beard, B.L. and McManus, J. (2006) The effect of early diagenesis on the Fe isotope compositions of porewaters and authigenic minerals in continental margin sediments. Geochimica et Cosmochimica Acta 70, 2006-2022. 
Severmann, S., McManus, J., Berelson, W.M. and Hammond, D.E. (2010) The continental shelf benthic iron flux and its isotope composition. Geochimica et Cosmochimica Acta 74, 3984-4004.

Shaw, T.J., Gieskes, J.M. and Jahnke, R.A. (1990) Early diagenesis in differing depositional environments: The response of transition metals in pore water. Geochimica et Cosmochimica Acta 54, 1233-1246. Intermediate Water. Journal of Physical Oceanography 31, 1005-1030.

Sommer, S., Gier, J., Treude, T., Lomnitz, U., Dengler, M., Cardich, J. and Dale, A.W. (2016) Depletion of oxygen, nitrate and nitrite in the Peruvian oxygen minimum zone cause an imbalance of benthic nitrogen fluxes. Deep Sea Research Part I: Oceanographic Research Papers 112, 113-122.

Stramma, L., Johnson, G.C., Sprintall, J. and Mohrholz, V. (2008) Expanding oxygen-minimum zones in the tropical oceans. Science 320, 655-658.

Straub, K.L., Benz, M., Schink, B. and Widdel, F. (1996) Anaerobic, nitrate-dependent microbial oxidation of ferrous iron. Applied and Environmental Microbiology 62, 1458-1460.

Suess, E., Kulm, L.D. and Killingley, J.S. (1987) Coastal upwelling and a history of organic-rich mudstone deposition off Peru, in: Brook, J., Fleet, A.J. (Eds.), Geological Society Special Publication, pp. 181-197.

Suits, N.S. and Arthur, M.A. (2000) Sulfur diagenesis and partitioning in Holocene Peru shelf and upper slope sediments. Chemical Geology 163, 219-234.

Sweere, T., van den Boorn, S., Dickson, A.J. and Reichart, G.-J. (2016) Definition of new trace-metal proxies for the controls on organic matter enrichment in marine sediments based on $\mathrm{Mn}, \mathrm{Co}$, Mo and Cd concentrations. Chemical Geology 441, 235-245.

Talley, L.D. (1993) Distribution and formation of North Pacific Intermediate Water. Journal of Physical Oceanography 23, 517-537.

Teng, F.-Z., Dauphas, N. and Watkins, J.M. (2017) Non-traditional stable isotopes: Retrospective and prospective. Reviews in Mineralogy and Geochemistry 82, 1-26.

1110 Thamdrup, B. and Canfield, D.E. (1996) Pathways of carbon oxidation in continental margin sediments off central Chile. Limnol. Oceanogr. 41, 1629-1650.

Thamdrup, B., Dalsgaard, T. and Revsbech, N.P. (2012) Widespread functional anoxia in the oxygen minimum zone of the Eastern South Pacific. Deep Sea Research Part I: Oceanographic Research Papers 65, 36-45. 
1115 Tosca, N.J., Guggenheim, S. and Pufahl, P.K. (2016) An authigenic origin for Precambrian greenalite: Implications for iron formation and the chemistry of ancient seawater. Geological Society of America Bulletin 128, 511-530.

Tribovillard, N., Algeo, T.J., Lyons, T.W. and Riboulleau, A. (2006) Trace metals as paleoredox and paleoproductivity proxies: An update. Chemical Geology 232, 12-32.

1120 Tribovillard, N., Riboulleau, A., Lyons, T. and Baudin, F. (2004) Enhanced trapping of molybdenum by sulfurized marine organic matter of marine origin in Mesozoic limestones and shales. Chemical Geology 213, 385-401.

Tyrrell, T. (1999) The relative influences of nitrogen and phosphorus on oceanic primary production. Nature 400, 525-531.

1125 Ulloa, O., Canfield, D.E., DeLong, E.F., Letelier, R.M. and Stewart, F.J. (2012) Microbial oceanography of anoxic oxygen minimum zones. Proceedings of the National Academy of Sciences 109, 15996-16003.

Van Cappellen, P. and Ingall, E.D. (1994) Benthic phosphorus regeneration, net primary production, and ocean anoxia: A model of the coupled marine biogeochemical cycles of carbon and phosphorus. Paleoceanography 9, 677-692.

1130 Van der Weijden, C.H., Reichart, G.J. and Visser, H.J. (1999) Enhanced preservation of organic matter in sediments deposited within the oxygen minimum zone in the northeastern Arabian Sea. Deep Sea Research Part 46, 807-830.

Vedamati, J., Goepfert, T. and Moffett, J.W. (2014) Iron speciation in the eastern tropical South Pacific oxygen minimum zone off Peru. Limnol. Oceanogr. 59, 1945-1957.

1135 Vorlicek, T.P., Helz, G.R., Chappaz, A., Vue, P., Vezina, A. and Hunter, W. (2018) Molybdenum Burial Mechanism in Sulfidic Sediments: Iron-Sulfide Pathway. ACS Earth and Space Chemistry 2, 565-576.

Wallmann, K. (2003) Feedbacks between oceanic redox states and marine productivity: A model perspective focused on benthic phosphorus cycling. Global Biogeochemical Cycles 17, 1084.

Wallmann, K. (2010) Phosphorus imbalance in the global ocean? Global Biogeochemical Cycles 24, DOI: 10.1029/2009GB003643.

Wanty, R.B. and Goldhaber, M.B. (1992) Thermodynamics and kinetics of reactions involving vanadium in natural systems: Accumulation of vanadium in sedimentary rocks. Geochimica et Cosmochimica Acta $56,1471-1483$.

Wehrli, B. and Stumm, W. (1989) Vanadyl in natural waters: Adsorption and hydrolysis promote 1145 oxygenation. Geochimica et Cosmochimica Acta 53, 69-77. 
Wijsman, J.W.M., Middelburg, J.J. and Heip, C.H.R. (2001) Reactive iron in Black Sea sediments: Implications for iron cycling. Marine Geology 172, 167-180.

Zhang, S., Wang, X., Wang, H., Bjerrum, C.J., Hammarlund, E.U., Costa, M.M., Connelly, J.N., Zhang, B., Su, J. and Canfield, D.E. (2016) Sufficient oxygen for animal respiration 1,400 million years ago. Proceedings of the National Academy of Sciences, doi.org/10.1073/pnas.1523449113.

Zheng, Y., Anderson, R.F., van Geen, A. and Kuwabara, J. (2000) Authigenic molybdenum formation in marine sediments: A link to pore water sulfide in the Santa Barbara Basin. Geochimica Et Cosmochimica Acta 64, 4165-4178.

\section{Figure captions}

1155 Figure 1. Biogeochemical cycling in the water column and sediments of oxygen minimum zones: (A) Schematic sketch illustrating element fluxes (arrows, colors are indicative for elements or species) and turnover. The size and direction of arrows is indicative of the flux magnitude and direction relative to the sediment-water interface or geometry of the continental margin. Note that only processes that are relevant for the discussion of proxy signatures are considered. Trace metal cycling is presented in a

1160 generalized fashion to provide an overview about relevant processes. (B) Examples for water column and pore water profiles of major redox species in the Peruvian OMZ (Scholz et al., 2011, 2016).

Figure 2. Biogeochemical cycling in the water column of the euxinic Black Sea: (A) Schematic sketch illustrating element fluxes and turnover. See Figure 1A for details. (B) Examples for water column profiles of major redox species in the Black Sea (Friederich et al., 1990; Lewis and Landing., 1991).

1165 Figure 3. Examples for water column profiles of major redox species in the Peruvian OMZ during a sulfidic event in the water column (Scholz et al., 2016). The maxima in $\mathrm{H}_{2} \mathrm{~S}$ and $\mathrm{Fe}^{2+}$ (depth depicted by horizontal arrow) were formed by lateral transport of water masses from shallower areas.

Figure 4. Biogeochemical feedbacks which can amplify (green arrows) or mitigate (red arrows) OMZ intensity and expansion. (A) Negative feedback for primary production, organic matter (OM) export and 1170 oxidant consumption through denitrification (Canfield, 2006). (B) Positive feedback through sedimentary Fe and $\mathrm{PO}_{4}{ }^{3-}$ release (Ingall and Jahnke, 1994; Van Capellen and Ingall, 1994; Scholz et al., 2014c). (C) Cancelation of the negative feedback in (A) by nitrogen fixation (Canfield, 2006). Nitrogen-fixing organisms are favored by low nitrogen to phosphorus ratios and high Fe supply related to sedimentary $\mathrm{PO}_{4}{ }^{3-}$ and Fe release. The feedback in (C) could transfer an $\mathrm{OMZ}$ from a nitrogenous to a euxinic mean 1175 redox state. 
Figure 5. Schematic comparison of trace metal- and iron-based paleo-redox proxy signatures in (A) the Peruvian OMZ and (B) the euxinic Black Sea (after Böning et al. (2004); Brumsack (2006); Lyons and Severmann (2006); Raiswell and Canfield (1998); Scholz et al. (2011, 2014a, b); Wijsman et al., (2001)). The principle processes leading to the formation of proxy signatures are indicated as well (see Fig. 1 and Fig. 2 for details). Horizontal dashed lines in the $\mathrm{Mn} / \mathrm{Al}$ and $\mathrm{Fe}_{\mathrm{T}} / \mathrm{Al}$ diagrams depict the composition of lithogenic material. Horizontal dashed lines in the $\mathrm{Fe}_{\mathrm{HR}} / \mathrm{Fe}_{\mathrm{T}}$ and $\mathrm{Fe}_{\mathrm{py}} / \mathrm{Fe}_{\mathrm{HR}}$ diagrams depict threshold values for anoxic and euxinic conditions, respectively (Raiswell and Canfield et al., 1998; Poulton and Canfield, 2011).

Figure 6. Theoretical framework for the interpretation of sedimentary Fe enrichment and depletion: (A)

$1185 \mathrm{Fe}_{\mathrm{T}} / \mathrm{Al}$ as a function of benthic Fe efflux (negative sign on $\mathrm{x}$-axis), authigenic Fe rain rate (positive sign on $\mathrm{x}$-axis) and sediment mass accumulation rate (MAR) (colored lines); the black star depicts the $\mathrm{Fe}_{\mathrm{T}} / \mathrm{Al}$ of the average upper continental crust (McLennan, 2001). (B) $\mathrm{Fe}_{\mathrm{HR}} / \mathrm{Fe}_{\mathrm{T}}$ as a function of benthic Fe efflux, authigenic Fe rain rate and MAR; the black star depicts the average $\mathrm{Fe}_{\mathrm{HR}} / \mathrm{Fe}_{\mathrm{T}}$ of continental margin sediments with oxic bottom water (Poulton and Raiswell, 2002). (C) Relationships shown in (A) and (B) in

1190 a cross plot of $\mathrm{Fe}_{\mathrm{T}} / \mathrm{Al}$ versus $\mathrm{Fe}_{\mathrm{HR}} / \mathrm{Fe}_{\mathrm{T}}$; symbols depict the average $\mathrm{Fe}_{\mathrm{T}} / \mathrm{Al} \pm \mathrm{SD}$ and $\mathrm{Fe}_{\mathrm{HR}} / \mathrm{Fe}_{\mathrm{T}} \pm \mathrm{SD}$ of sediment cores from the OMZs off the coast of Peru (Scholz et al., 2014b, c) and in the Gulf of California (F. Scholz, unpublished data; see Supplementary Information for further details). The range of $\mathrm{Fe}_{\mathrm{T}} / \mathrm{Al}$ and $\mathrm{Fe}_{\mathrm{HR}} / \mathrm{Fe}_{\mathrm{T}}$ observed in pelagic Black Sea sediments is shown for comparison (Raiswell and Canfield, 1998; Lyons and Severmann, 2006). The trend depicting delivery of $\mathrm{Fe}_{\mathrm{HR}}$ and authigenesis of Fe silicate minerals 1195 was calculated by using a 1:9 ratio between newly delivered and pre-existing $\mathrm{Fe}_{\mathrm{HR}}$ that is incorporated into silicate minerals. (D) Close-up of (C) showing OMZ sediments in greater detail. See Supplementary Information for further details about the underlying calculations.

Figure 7. Shelf-to-slope distribution of bottom water oxygen concentrations, sedimentary trace metal enrichments (expresses as excess metal concentrations relative to the metal to Al ratio of the upper 1200 continental crust; see Supplementary Information) and logarithmic trace metal ratios $\left(\log (\mathrm{Me} / \mathrm{Me})_{x s}\right)$ across the Peruvian continental margin at $11^{\circ} \mathrm{S}$ (data from Scholz et al. (2011)). Element concentration ratios are presented as logarithmic ratios to avoid asymmetry effects. The logarithmic trace metal ratio in seawater and composition of Holocene Black Sea sediments (range between the average of Unit 1 and Unit 2 sediments) (Brumsack, 2006) are shown for comparison.

1205 Figure 8. (A) Cross plot of $\mathrm{Fe}_{\mathrm{py}} / \mathrm{Fe}_{\mathrm{HR}}$ versus $\mathrm{Fe}_{\mathrm{HR}} / \mathrm{Fe}_{\mathrm{T}}$ with fields for oxic, ferruginous and euxinic proxy signatures (Poulton and Canfield, 2011). Symbols depict the average $\mathrm{Fe}_{\mathrm{py}} / \mathrm{Fe}_{\mathrm{HR}} \pm \mathrm{SD}$ and $\mathrm{Fe}_{\mathrm{HR}} / \mathrm{Fe}_{\mathrm{T}} \pm \mathrm{SD}$ of sediment cores from the Peruvian continental margin (Scholz et al., 2014c) and the Gulf of California (F. 
Scholz, unpublished data; see Supplementary Information for further details). Only sediment cores with elevated $\mathrm{Fe}_{\mathrm{HR}} / \mathrm{Fe}_{\mathrm{T}}$ relative to sediments with oxic bottom water are shown (see Fig. $6 \mathrm{C}$ ). The arrows 1210 were calculated under the assumption that the sediment cores had a one order of magnitude lower sediment mass accumulation rate (i.e., approximately similar to the Black Sea) but the same authigenic Fe rain rate (Fig. $6 \mathrm{~B}$ ). The high $\mathrm{SD}$ of $\mathrm{Fe}_{\mathrm{py}} / \mathrm{Fe}_{\mathrm{HR}}$ is related to the downcore increase in pyritization because of increasing $\mathrm{H}_{2} \mathrm{~S}$ concentrations in the pore water (Scholz et al., 2014c). (B) Cross plot of $\mathrm{Fe}_{\mathrm{T}} / \mathrm{Al}$ versus $\mathrm{Fe}_{\mathrm{HR}} / \mathrm{Fe}_{\mathrm{T}}$ illustrating the impact of terrestrial weathering intensity on the trend line for sedimentary $\mathrm{Fe}$ 1215 release and trapping. See Supplementary Information for further details about the underlying calculations.

Figure 9. Proxy-based scheme for the identification of different types of anoxic settings in the geological record: restricted basin-type versus open-marine with nitrogenous, weakly sulfidic, ferruginous (with or without leftover sulfate) or euxinic conditions in the water column. A 'weakly sulfidic' water column is characterized by hydrogen sulfide concentrations below FeS saturation whereas a euxinic water column is saturated with respect to FeS (see Section 2.3). Threshold values of Cd/Mo are from Sweere et al. (2016). Regional nitrogen isotope variability has to be interpreted relative to the global secular $\delta^{15} \mathrm{~N}$ trend (see Section 3.3 for further information). The nitrogen isotopic trends are tentative (e.g., coeval assimilation and nitrification of ammonia is neglected) (Ader et al., 2016) and meant to provide a basis for discussion. 
Table 1. Biogeochemical conditions and processes across OMZs and associated paleo-redox proxies.

\begin{tabular}{|c|c|}
\hline Biogeochemical conditions and processes & Paleo-redox proxy \\
\hline \multicolumn{2}{|l|}{ Redox conditions (see Fig. 7 for details) } \\
\hline Anoxic water column (open-marine) & $\mathrm{Mn} / \mathrm{Al}<\mathrm{UCC}^{1}$ \\
\hline Oxic surface sediment & $(\mathrm{Mo} / \mathrm{U})_{\mathrm{XS}}<\mathrm{UCC}$ \\
\hline Ferruginous surface sediment & $\mathrm{UCC} \leq(\mathrm{Mo} / \mathrm{U})_{\mathrm{XS}}<$ seawater \\
\hline Sulfidic surface sediment & $(\mathrm{Mo} / \mathrm{U})_{\mathrm{XS}} \geq$ seawater \\
\hline \multicolumn{2}{|l|}{ Iron cycle } \\
\hline $\begin{array}{l}\text { Reactive Fe release or trapping, Fe mobility in surface sediment } \\
\text { and bottom water (see trend line in Fig. } 6 \mathrm{C} \text { ) }\end{array}$ & $\mathrm{Fe}_{\mathrm{HR}} / \mathrm{Fe}_{\mathrm{T}}, \mathrm{Fe}_{\mathrm{T}} / \mathrm{Al}$ \\
\hline Pyritization, Fe trapping, retention and burial & $\mathrm{Fe}_{\mathrm{py}} / \mathrm{Fe}_{\mathrm{HR}}$ \\
\hline \multicolumn{2}{|l|}{ Phosphorous cycle } \\
\hline $\mathrm{P}$ release & $\mathrm{C} / \mathrm{P}$ (relative to phytoplankton) \\
\hline $\mathrm{P}$ burial & $\mathrm{P} / \mathrm{Al}$, phosphorous speciation \\
\hline \multicolumn{2}{|l|}{ Nitrogen cycle (water column) } \\
\hline Denitrification, anammox, nitrogen fixation & $\delta^{15} \mathrm{~N}$, biomarker \\
\hline
\end{tabular}

${ }^{1}$ UCC: Upper continental crust (McLennan, 2001). 
A

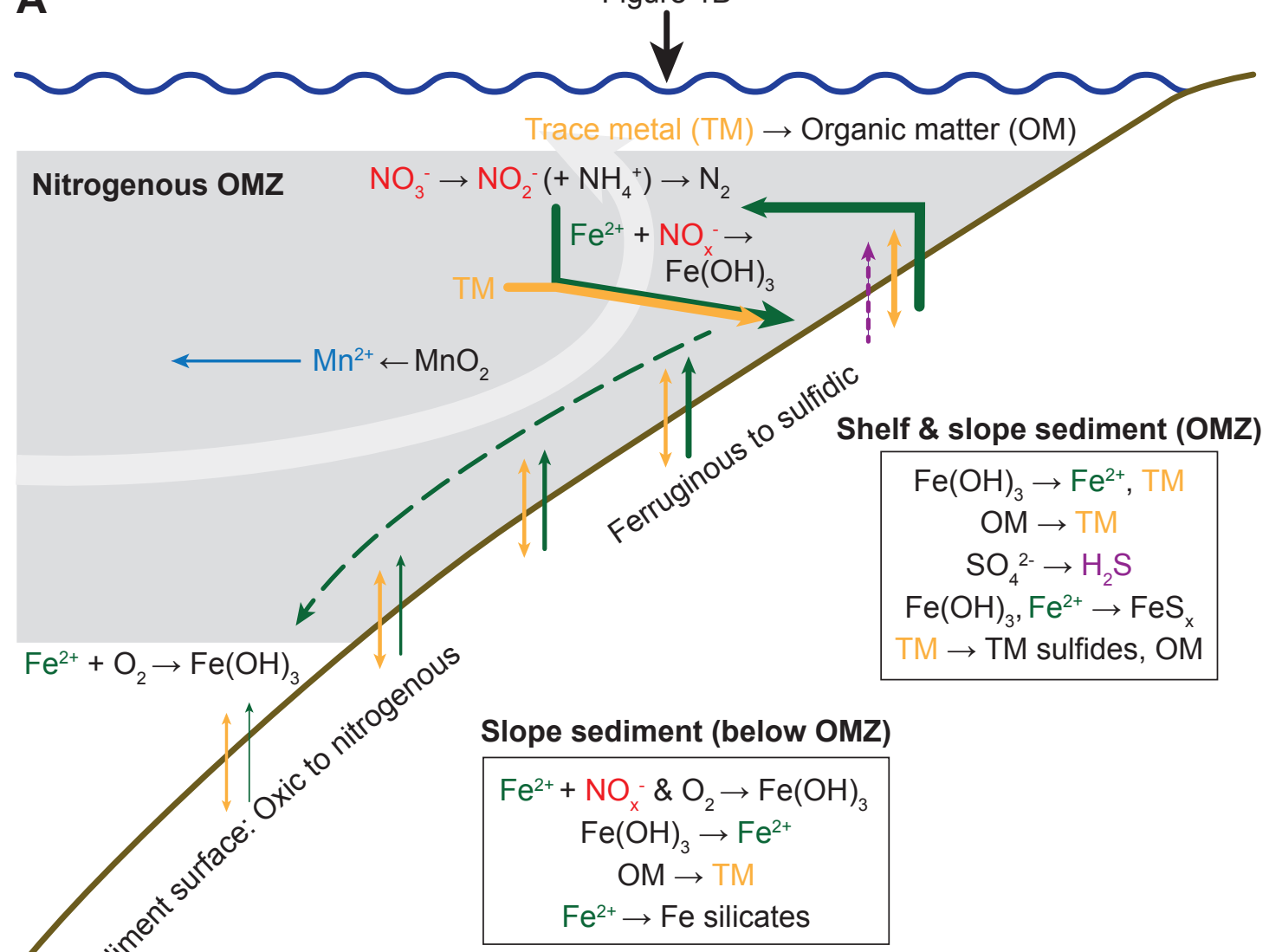

$s^{e}$

B

$\mathrm{O}_{2}(\mu \mathrm{M})$

Nitrogen species ( $\mu \mathrm{M})$

$\mathrm{Fe}^{2+}(\mathrm{nM})$

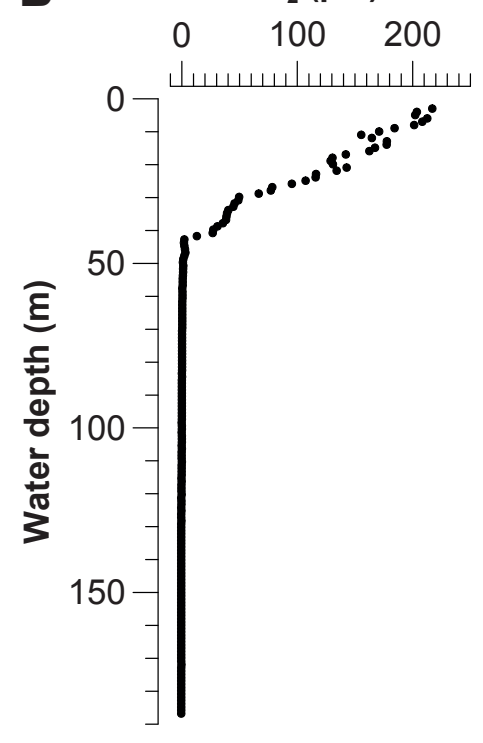

$\begin{array}{lllllllll}0 & 10 & 20 & 30 & 0 & 5 & 10 & 15 & 20\end{array}$

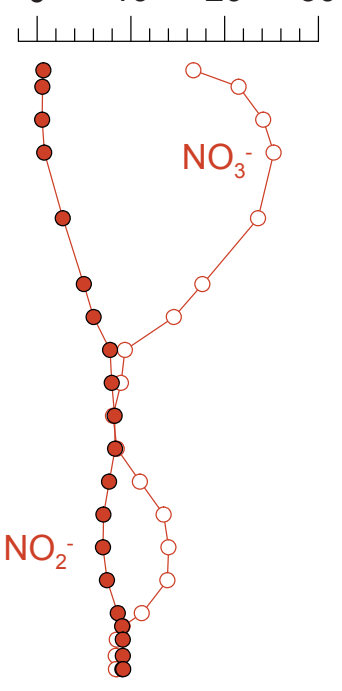

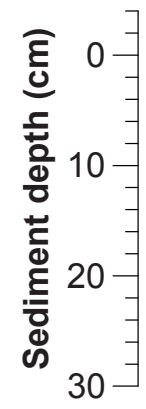

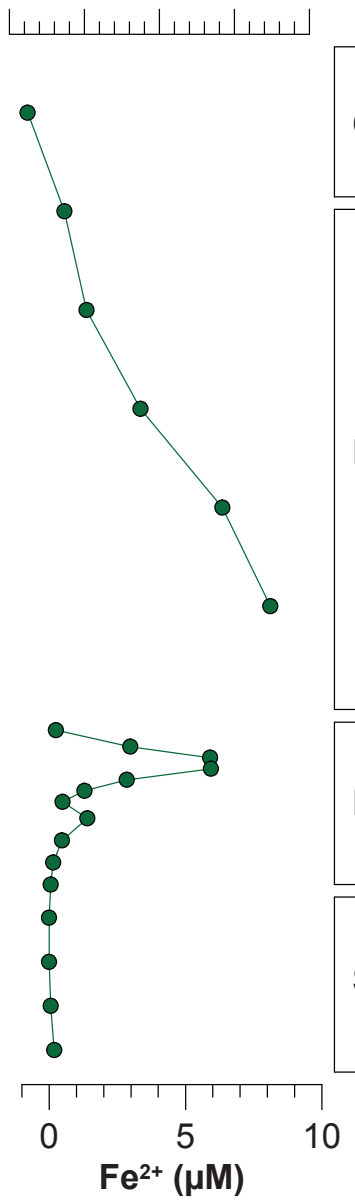

Nitrogenous OMZ

Sediment-water

interface

Ferruginous

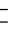

Sulfidic

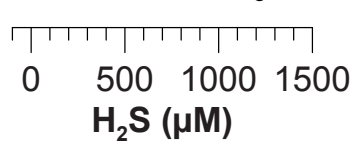

$\mathrm{Fe}^{2+}(\mu \mathrm{M})$

Figure 1 

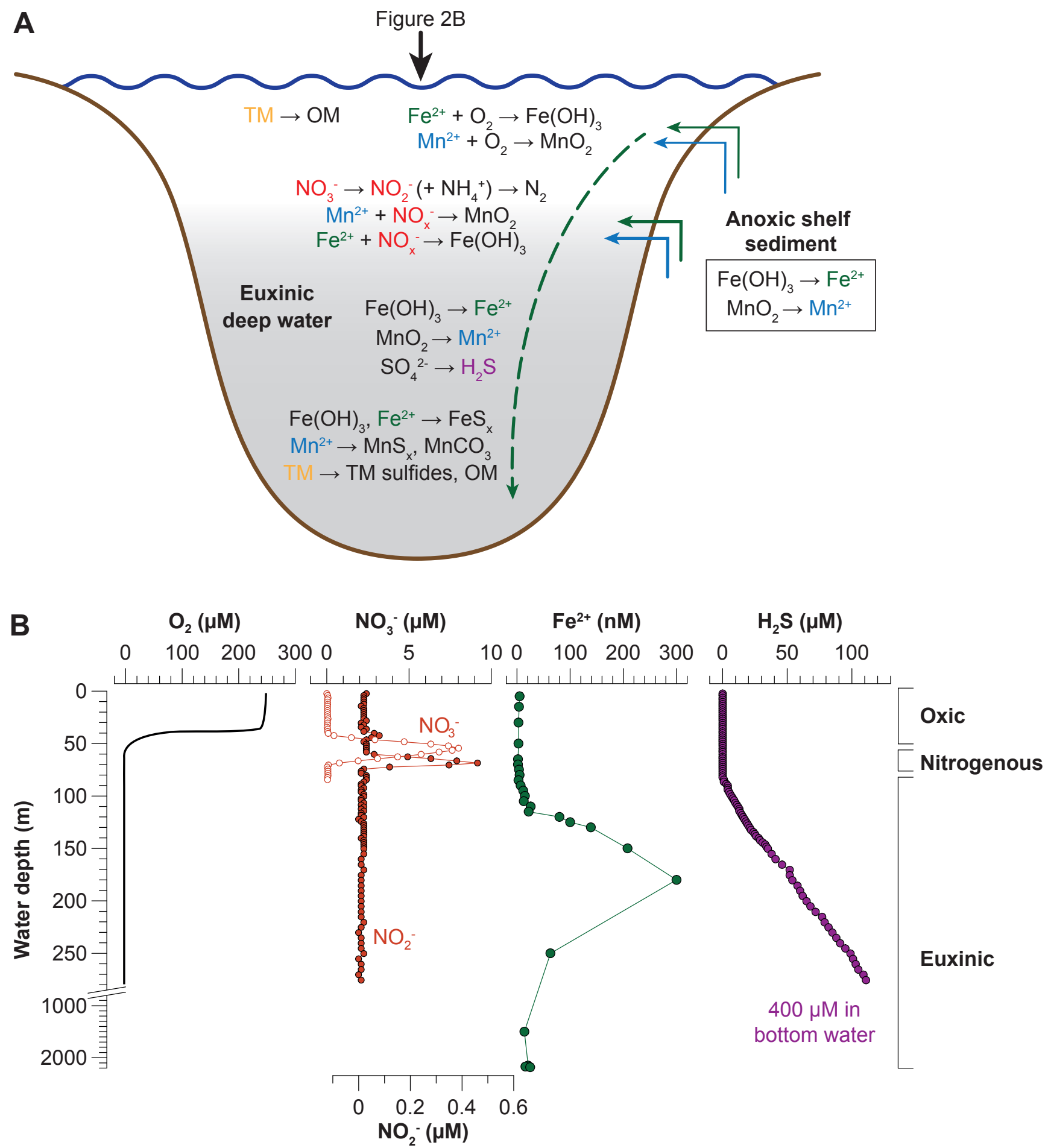

Figure 2 


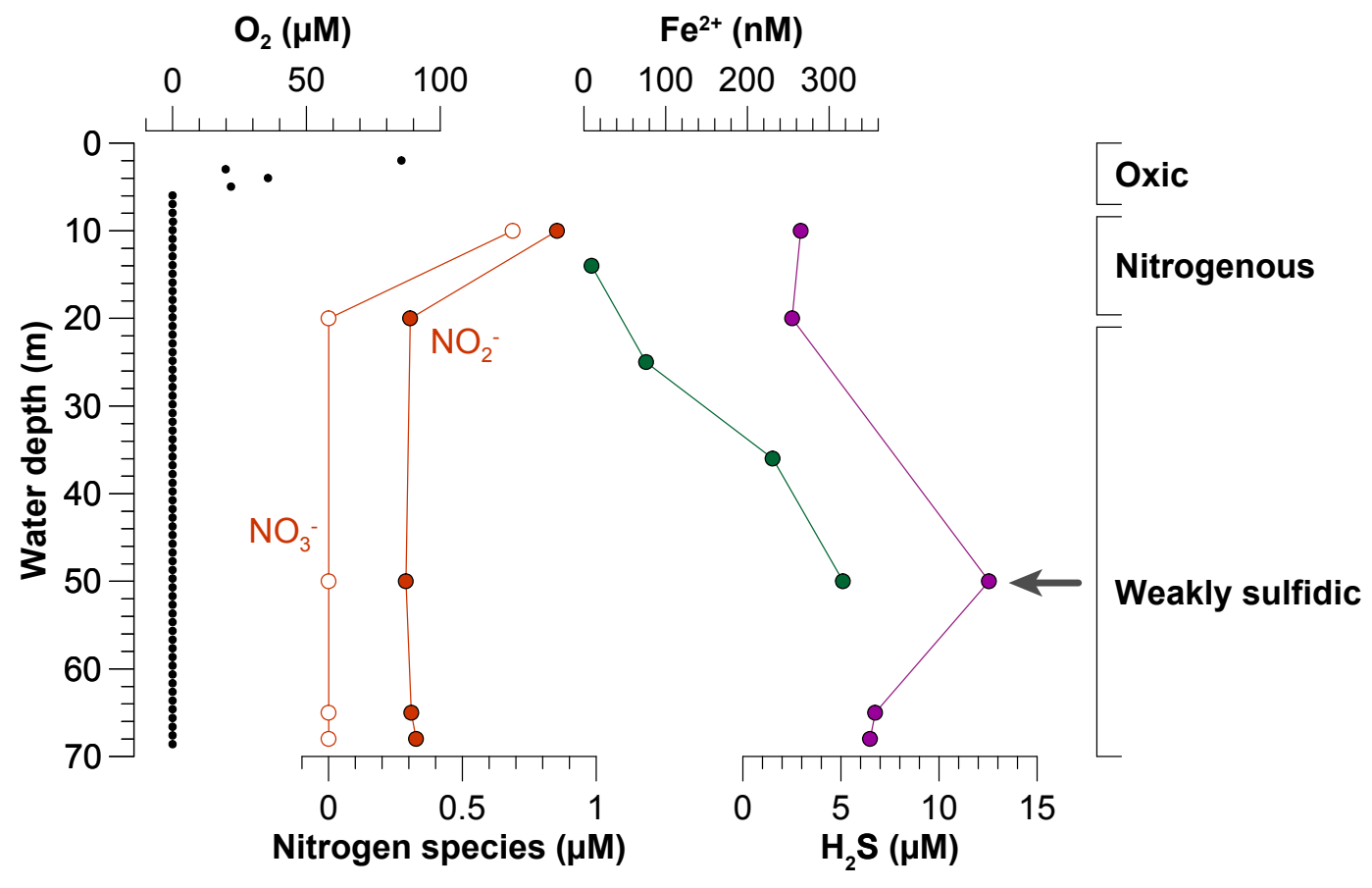

Figure 3 


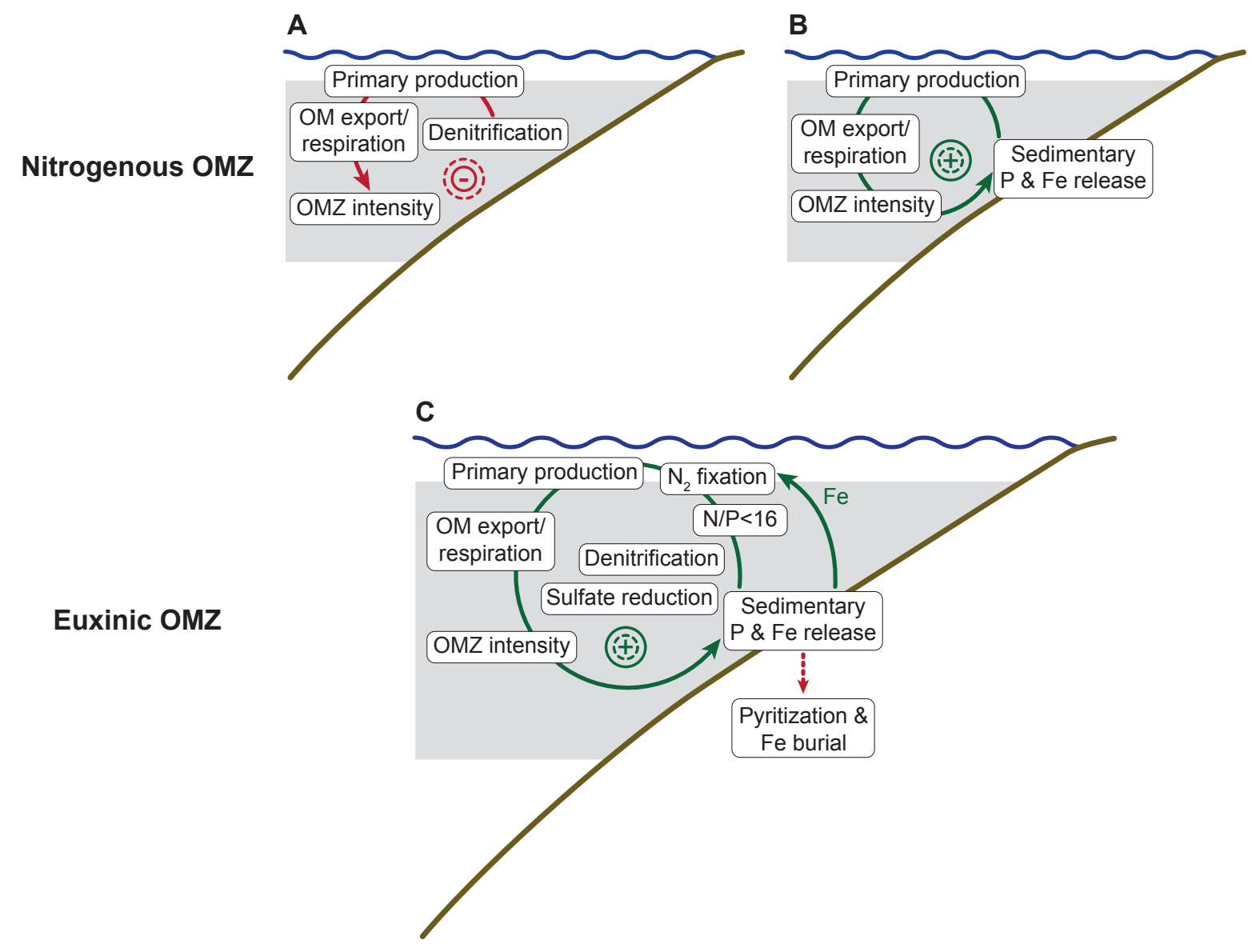

Figure 4 
A

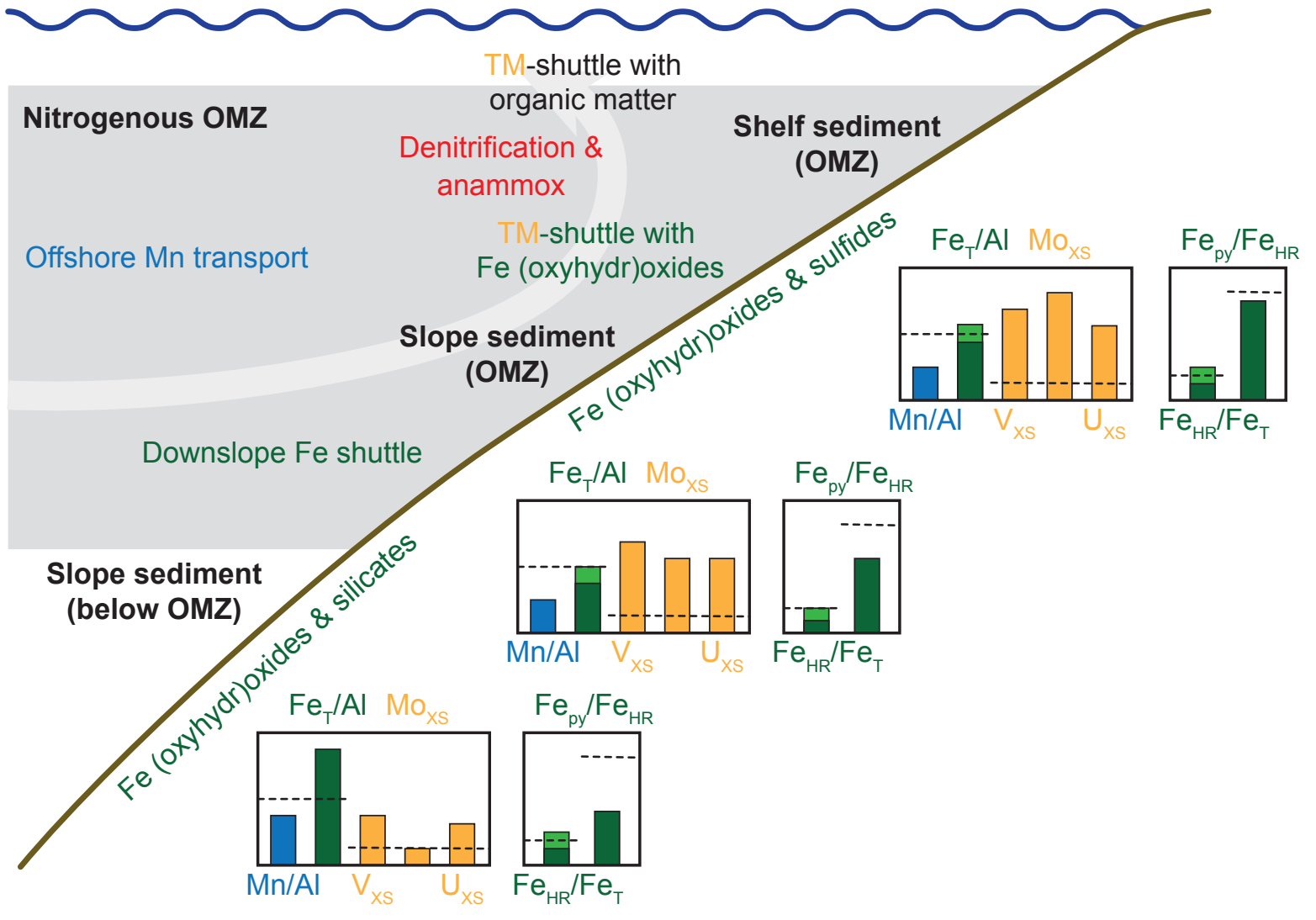

B

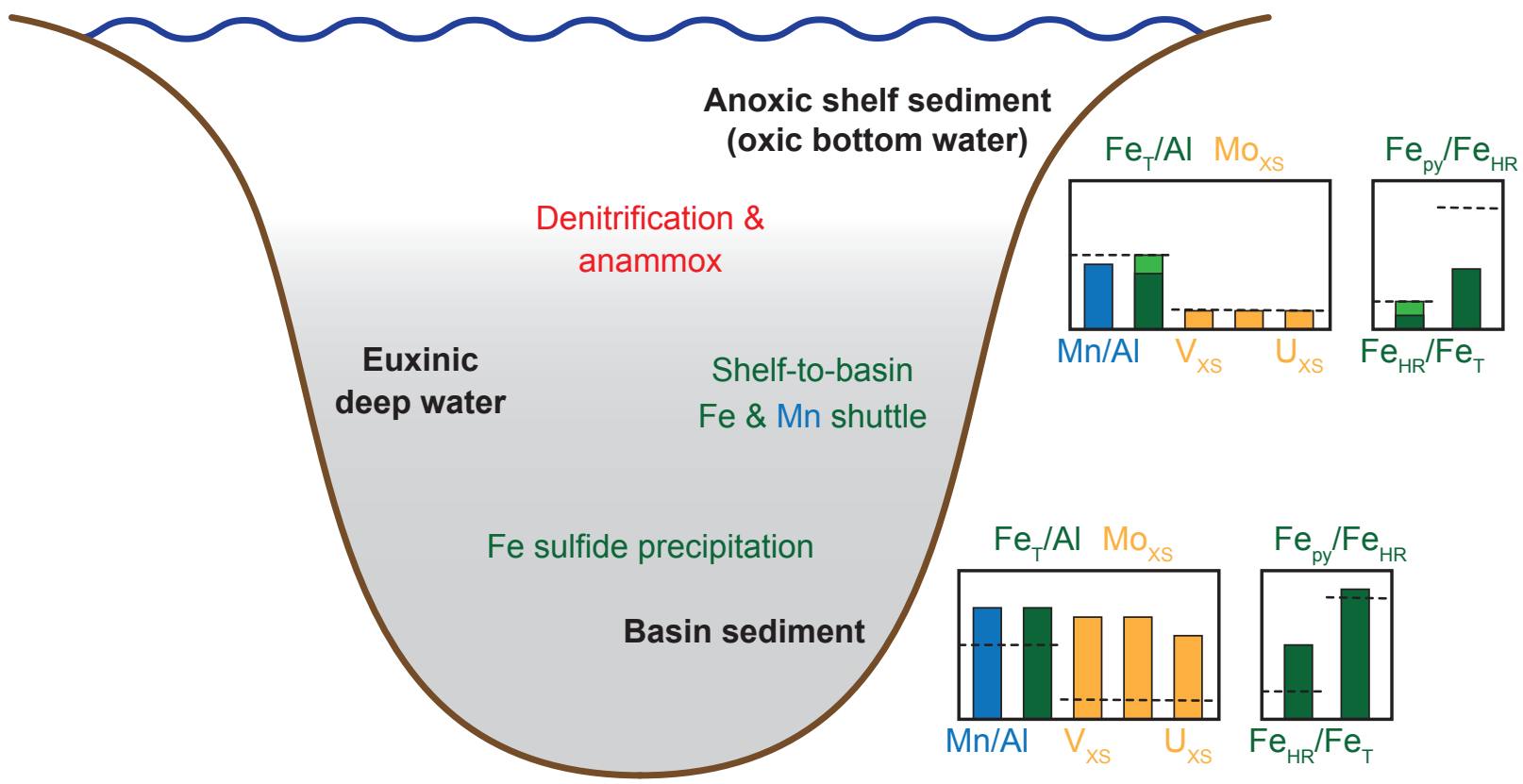

Figure 5 


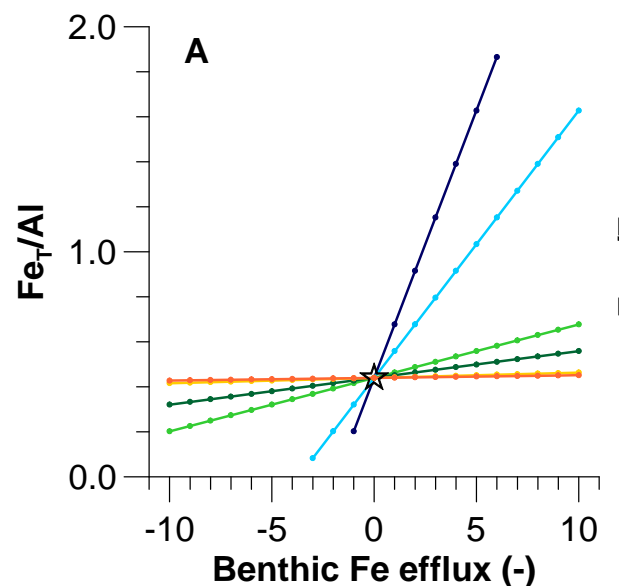

Benthic Fe efflux (-)

Authigenic Fe rain rate (+) $\left(\mu \mathrm{mol} \mathrm{cm}{ }^{-2} \mathrm{yr}^{-1}\right)$

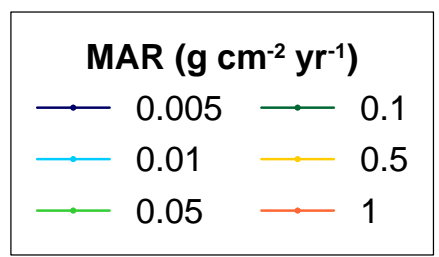

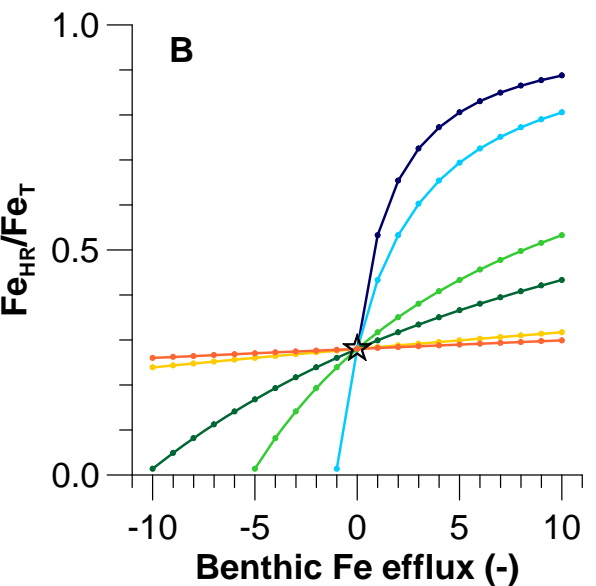

Authigenic Fe rain rate (+) $\left(\mu \mathrm{mol} \mathrm{cm}{ }^{-2} \mathrm{yr}^{-1}\right)$

\section{Continental crust/}

ț continental margin sediment with oxic bottom water

- Peru shelf, $145 \mathrm{~m}$ (anoxic)

$\diamond$ Peru slope, $320 \mathrm{~m}$ (anoxic) Peru slope, $930 \mathrm{~m}$

$\left(40 \mu \mathrm{M} \mathrm{O}_{2}\right)$

Gulf of California, $665 \mathrm{~m}$ (anoxic)

Gulf of California, $1220 \mathrm{~m}\left(17 \mu \mathrm{M} \mathrm{O}_{2}\right)$
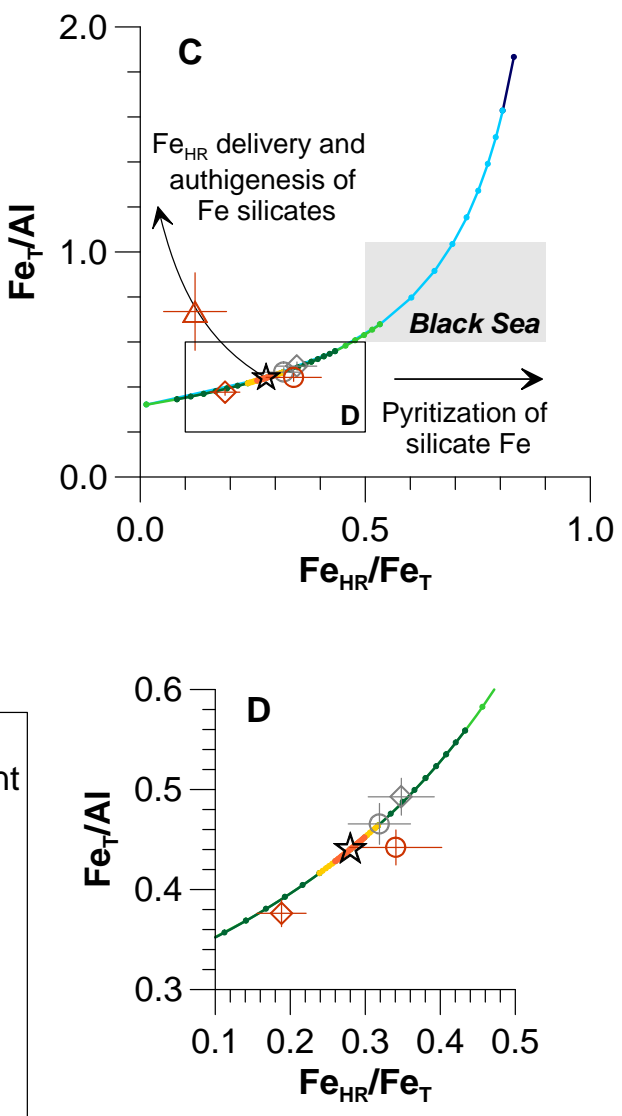

Figure 6 


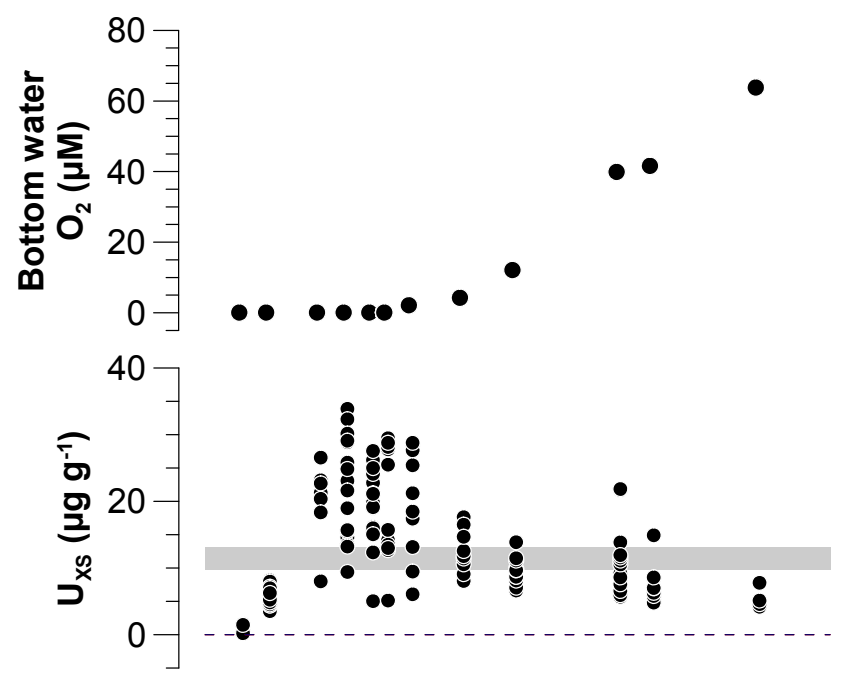

- Peru margin

Black Sea

Terrigenous

background/unity

Seawater
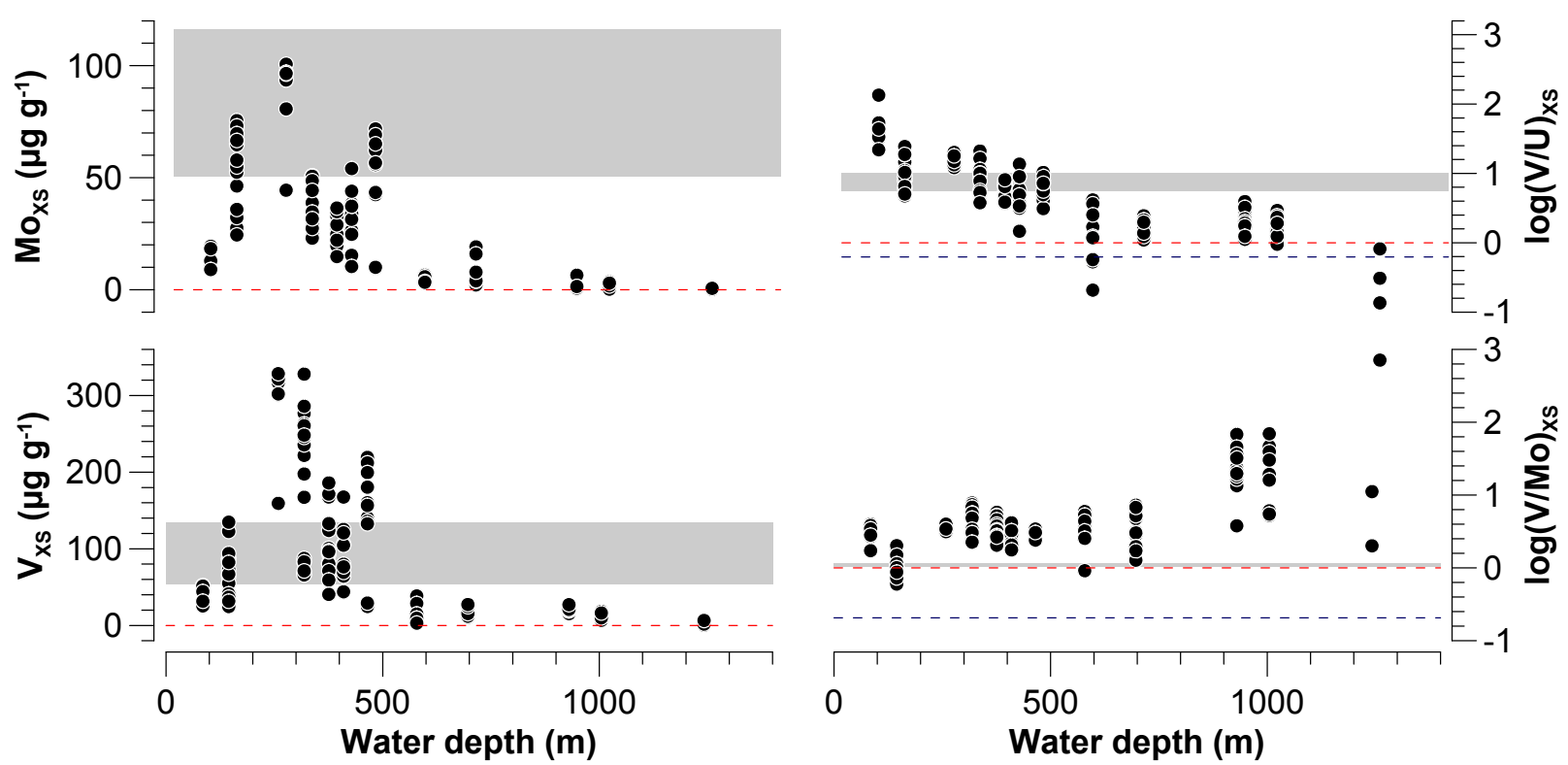

Figure 7 


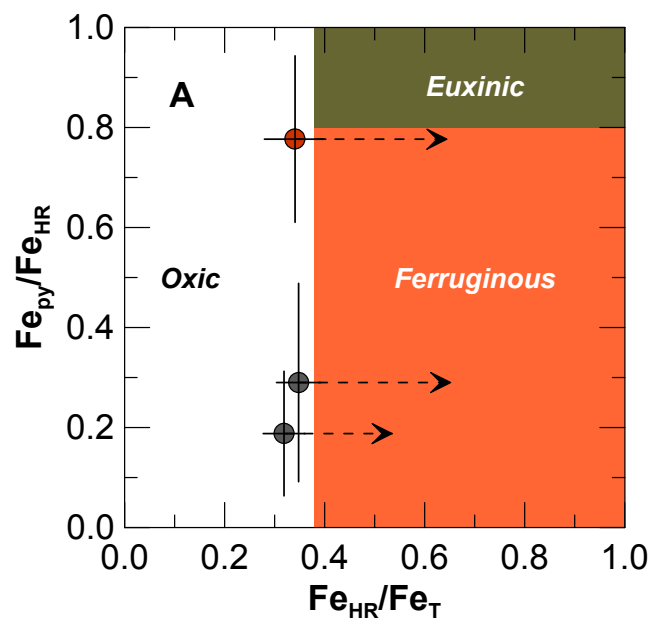

- Peru shelf

- Gulf of California

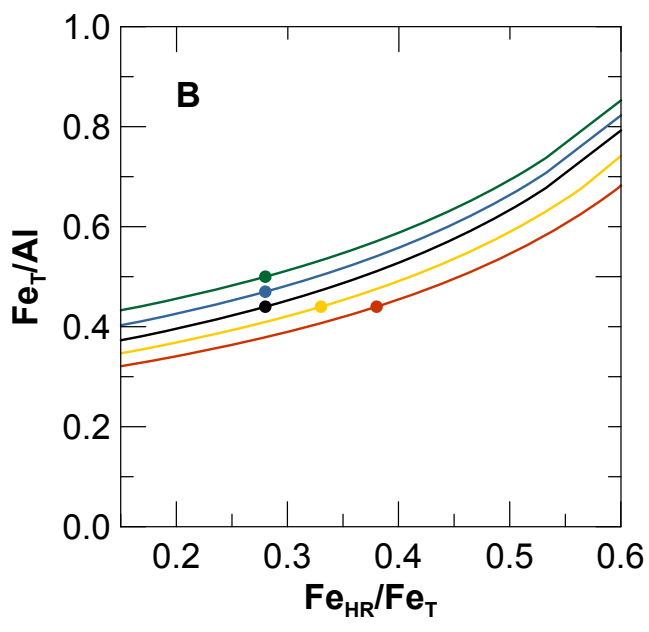

- Modern ocean (Fig. 6C)

- $\mathrm{Fe}_{\mathrm{HR}} / \mathrm{Fe}_{\mathrm{T}}=0.33$

- $\mathrm{Fe}_{\mathrm{HR}} / \mathrm{Fe}_{\mathrm{T}}=0.38$

$-\mathrm{Fe}_{\mathrm{T}} / \mathrm{Al}=0.47$

$\mathrm{Fe}_{\mathrm{T}} / \mathrm{Al}=0.50$

Figure 8 


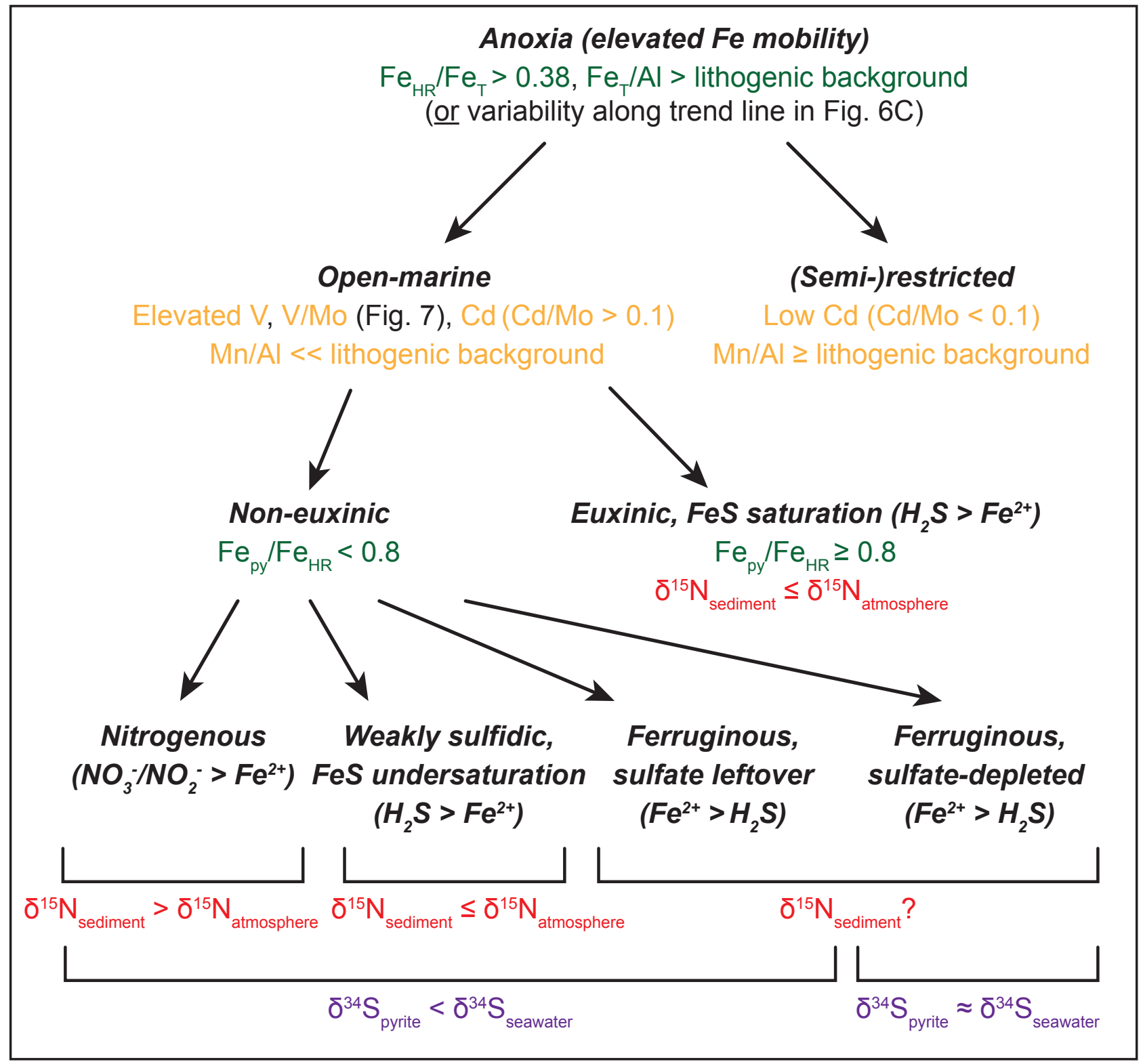

Figure 9 


\title{
Identifying oxygen minimum zone-type biogeochemical cycling in Earth history using inorganic geochemical proxies - Supplementary Information
}

\author{
Florian Scholz*
}

GEOMAR Helmholtz Centre for Ocean Research Kiel, Wischhofstraße 1-3, 24148 Kiel, Germany

$5 \quad$ *Corresponding author: e-mail: fscholz@geomar.de, phone: +49 (0)431 6002113

\section{Generalized model for sedimentary iron release and trapping}

The $\mathrm{Fe}_{\mathrm{T}} / \mathrm{Al}$ and $\mathrm{Fe}_{\mathrm{HR}} / \mathrm{Fe}_{\mathrm{T}}$ after reactive $\mathrm{Fe}$ release or trapping were calculated with the following equations:

$$
\begin{gathered}
F e_{T} / A l=\frac{M A R \cdot A l \cdot\left(\frac{F e_{T}}{A l}\right)_{c r u s t}+\left(\left(R R_{F e}, F_{F e}\right) \cdot M_{F e}\right)}{M A R \cdot A l} \\
F e_{H R} / F e_{T}=\frac{M A R \cdot A l \cdot\left(\frac{F e_{T}}{A l}\right)_{c r u s t} \cdot\left(\frac{F e_{H R}}{F e_{T}}\right)_{\text {oxic }}+\left(\left(R R_{F e}, F_{F e}\right) \cdot M_{F e}\right)}{M A R \cdot A l \cdot\left(\frac{F e_{T}}{A l}\right)_{\text {crust }}+\left(\left(R R_{F e}, F_{F e}\right) \cdot M_{F e}\right)}
\end{gathered}
$$

MAR: Sediment mass accumulation rate, in $\mathrm{g} \mathrm{cm}^{-2} \mathrm{yr}^{-1}$.

10 Al: Aluminum concentration in the sediment, in $\mathrm{mg} \mathrm{g}^{-1}$. Scenarios of Fe loss or gain where calculated by assuming using a sedimentary Al concentration of $50 \mathrm{mg} \mathrm{g}^{-1}$ which is consistent with published data for sediments on the Peruvian margin, in the Gulf of California and the Black Sea (Scholz et al., 2011; Brumsack, 2006).

(Fe/Al) crust $_{\text {Fe }} / \mathrm{Al}$ of the average upper continental crust, 0.44 (McLennan, 2001).

$15\left(\mathrm{Fe}_{\mathrm{HR}} / \mathrm{Fe}_{\mathrm{T}}\right)_{\text {oxic }}: \mathrm{Fe}_{\mathrm{HR}} / \mathrm{Fe}_{\mathrm{T}}$ of continental margin sediments with oxic bottom water, $0.28 \pm 0.06$ (Poulton and Raiswell, 2002).

$\mathrm{RR}_{\mathrm{Fe}}$ : Authigenic Fe rain rate, in $\mathrm{mmol} \mathrm{cm}^{-2} \mathrm{yr}^{-1}$ (positive sign).

$\mathrm{F}_{\mathrm{Fe}}$ : Benthic Fe efflux, in $\mathrm{mmol} \mathrm{cm}^{-2} \mathrm{yr}^{-1}$ (negative sign).

$\mathrm{M}_{\mathrm{Fe}}$ : Molar mass of $\mathrm{Fe}, 55.845 \mathrm{mg} \mathrm{mmol}^{-1}$. 
Sediment cores were collected in the Gulf of California during RV Sonne cruise SO241 in June and July 2015. Pore water recovery and sediment subsampling was realized in a glove bag under anoxic conditions as explained in Scholz et al. (2011). Total iron (Fe) and aluminum (Al) concentrations were determined after total digestion by inductively coupled plasma optical emission spectroscopy (ICP-OES)

25 (see Scholz et al. (2011) for details). Certified reference standards (SDO-1, USGS; MESS-3, Canadian Research Council) were digested and analyzed on a routine basis. The obtained values for Fe and Al were always within the certified ranges. A sequential sediment extraction for the recovery of highly reactive Fe phases was applied to the freeze-dried and ground sediment samples (Poulton and Canfield, 2005). An in-house standard (OMZ-1) and the Certified Reference Material PACS-3 (Canadian Research Council)

30 were extracted during each batch of sequential extractions. The results for the sum of highly reactive Fe without Fe bound to pyrite $\left(\mathrm{Fe}_{\mathrm{py}}\right)$ were consistent with data generated at the University of Southern Denmark (SDU) for the same standard material (GEOMAR, OMZ-1: $0.47 \pm 0.02$ wt. \%, $\mathrm{n}=18$, PACS-3: $1.25 \pm 0.01, \mathrm{n}=7$; SDU, OMZ-1: $0.44 \pm 0.05$ wt. \%, $\mathrm{n}=3$, PACS-3: $1.26 \pm 0.04, \mathrm{n}=12$ ). The chromium reduction method was used for the determination of $\mathrm{Fe}_{\mathrm{py}}$ (Canfield et al., 1986). The accuracy of the method was monitored by determining the pyrite content of mixtures between pure pyrite and quartz sand. The geochemical data for sediments from the Gulf of California are summarized in Supplementary Table S1.

\section{Calculation of excess trace metal concentrations}

Excess metal concentrations $\left(\mathrm{Me}_{\mathrm{xs}}\right.$ ) relative to the metal to Al ratio of the upper continental crust 40 (McLennan, 2001) were calculated with the following equation (e.g., Brumsack, 2006):

$$
M e_{X S}=M e-\left(\frac{M e}{A l}\right)_{\text {crust }} \cdot A l
$$

Mexs: Excess metal concentration, in $\mu \mathrm{g} \mathrm{g}^{-1}$.

$\mathrm{Me}_{\text {sample: }}$ Metal concentration in the sediment, in $\mu \mathrm{g} \mathrm{g}^{-1}$.

$\mathrm{Al}_{\text {sample: }}$ Metal concentration in the sediment, in $\mu \mathrm{g} \mathrm{g}^{-1}$.

$(\mathrm{Me} / \mathrm{Al})_{\text {crust }}: \mathrm{Me} / \mathrm{Al}$ of the average upper continental crust, $\mathrm{V}: 1.33 \cdot 10^{-3}, \mathrm{Mo:}: 1.9 \cdot 10^{-5}, \mathrm{U}: 3.5 \cdot 10^{-5}$ 45 McLennan, 2001). 


\section{References}

Brumsack H.-J. (2006) The trace metal content of recent organic carbon-rich sediments: Implications for Cretaceous black shale formation. Palaeogeography, Palaeoclimatology, Palaeoecology 232, 344-361.

Canfield D. E., Raiswell R., Westrich J. T., Reaves C. M., and Berner R. A. (1986) The use of chromium reduction in the analysis of reduced inorganic sulfur in sediments and shales. Chemical Geology 54, 149-155.

McLennan S. M. (2001) Relationships between the trace element composition of sedimentary rocks and upper continental crust. Geochemistry Geophysics Geosystems 2, paper number 2000GC000109.

Poulton S. W. and Raiswell R. (2002) The low-temperature geochemical cycle of iron: From continental fluxes to marine sediment deposition. American Journal of Science 302, 774-805.

Poulton S. W. and Canfield D. E. (2005) Development of a sequential extraction procedure for iron: implications for iron partitioning in continentally derived particulates. Chemical Geology 214, 209221.

Scholz F., Hensen C., Noffke A., Rohde A., Liebetrau V., and Wallmann K. (2011) Early diagenesis of redoxsensitive trace metals in the Peru upwelling area: response to ENSO-related oxygen fluctuations in the water column. Geochimica et Cosmochimica Acta 75, 7257-7276. 